\title{
Bank Market Power and Lending during the Global Financial Crisis
}

\author{
Elena Cubillas* \\ University of Oviedo \\ Nuria Suárez \\ Autónoma University of Madrid
}

\begin{abstract}
:
This research examines how the Global Financial Crisis (GFC) affected banks' supply of credit, not only in a direct way but also indirectly through changes in bank market power. We use a sample of 735 banks from 17 countries during the 2003-20I 2 period. We find that the direct negative impact of the GFC on banks' supply of loans is counteracted by an indirect effect through the increased level of bank market power in the years after the onset of the crisis. This result is particularly relevant in countries with less stringent restrictions on bank activities and less supervisory power.
\end{abstract}

\section{Keywords:}

Global Financial Crisis; Bank lending; Bank market power; Bank regulation and supervision

\footnotetext{
*University of Oviedo. School of Economics and Business. Avda. del Cristo, s/n. 33006 Oviedo (Spain). Phone: +34 985106203 E-mail: cubillaselena@uniovi.es

**Autónoma University of Madrid. School of Economics and Business. Francisco Tomás y Valiente, 5. 28049 Madrid (Spain). Phone: +34 914975744 E-mail:nuria.suarez@uam.es

†We thank Olivier De Jonghe, Ana I. Fernández, Angela Gallo, Francisco González, Alfredo Martín-Oliver, Rafael Santamaría (In loving memory), and an anonymous referee for helpful comments and suggestions. We also thank participants at the I International Workshop on Risk Management, Financial Regulation and Governance in Banking in Palermo (2016); at the XXIV Finance Forum in Madrid (2016); at the 2017 FMA Conference in Lisbon; at the INFINITI Conference on International Finance in Poznan (2018); and at ACEDE Conference in Valladolid (2018). We acknowledge financial support from the Spanish Ministry of Economy and Competitiveness (Projects MINECO-I6-ECO2016-79693-P and MINECO-16-ECO20I5$66 \mid 84-R)$. Financial support from FUNCAS (2015) is gratefully acknowledged. Nuria Suárez also acknowledges financial support from the Comunidad de Madrid Project S20I5/HUM-3353.
} 


\title{
Bank Market Power and Lending during the Global Financial Crisis
}

\begin{abstract}
:
This research examines how the Global Financial Crisis (GFC) affected banks' supply of credit, not only in a direct way but also indirectly through changes in bank market power. We use a sample of 735 banks from 17 countries during the 2003-20I 2 period. We find that the direct negative impact of the GFC on banks' supply of loans is counteracted by an indirect effect through the increased level of bank market power in the years after the onset of the crisis. This result is particularly relevant in countries with less stringent restrictions on bank activities and less supervisory power.
\end{abstract}

\section{Keywords:}

Global Financial Crisis; Bank lending; Bank market power; Bank regulation and supervision 


\section{INTRODUCTION}

The aim of this research work is to analyze how the Global Financial Crisis 2007/2008 (GFC) affected the amount of credit that banks were willing to lend. We distinguish the global effect of the crisis on banking lending from the specific effect that might have occurred as a result of the changes in market power experienced by banks during the financial turmoil.

It is widely accepted that banking crises have a negative effect on economic growth. While crises tend to occur when there are economic downturns, problems in the banking sector also have independent negative effects on the real economy. Papers such as Kroszner et al. (2007) or Dell'Ariccia et al. (2008) confirm that negative real effects persist even after accounting for reverse causality between an economic downturn and a banking crisis. More financially dependent industries perform significantly more poorly during banking crises than industries that are not so dependent on external funds. Kroszner et al. (2007), moreover, show that banking crises have a more strongly negative effect on growth in countries with more developed financial systems. The negative real effect of banking crises has been associated with a reduction in funds provided by banks (the lending channel).

Love et al. (2007) focus on the relationship between bank credit and trade credit during and after crises in six emerging economies. They show that the provision of trade credit decreases in the months and years following a crisis. The argument is that the decline in aggregate trade credit ratios is driven by the reduced supply of trade credit that arises during a bank credit crunch. Chava and Purnanandam (20II) focus on the causal relationship between adverse shocks to banks and borrowers' performance. They base their analysis on an event that was completely exogenous to the US banking system, the Russian crisis in 1998, to isolate the effect of borrowers' demand for credit from the supply of credit by banks. Their results show that the banks affected by the crisis decreased the amount lent and increased their interest rates. As a consequence, firms that relied more on this type of financing suffered larger losses during this period.

In our research we go one step further and examine how the GFC affected growth in net bank loans and how this effect could be related to changes in the level of bank market power after the onset of the crisis episode. The restructuring of banking sectors during crises involving the shutdown, merger or acquisition of failed banks may increase the market power of the surviving 
banks (Laeven and Valencia, 2008; 2012; Wheelock, 20II; Cubillas and Suárez, 20I3). In periods of crises and relying on the argument of high information asymmetries, banks would only have incentives to lend to borrowers with whom they have a longstanding lending relationship. However, if lending relationships collapse due to bank insolvency problems, borrowers are obliged to borrow from non-relationship banks to keep their investments. Since they need to find a new lender quickly, banks can afford to require higher interest rates in loan operations. For this reason, in spite of the high information asymmetries, surviving entities -enjoying a higher level of market powerwould be willing to provide funds to those non-relationship borrowers.

Recent studies have associated also the relationship between bank market power and credit supply with banks' access to alternative funding sources. Banks with high market power should have easy access to financial markets and, consequently, a greater ability to hedge against loan losses. As a result, they would probably cut their lending less than other banks would (Gambacorta and Marques-Ibanez, 20II; Brissimis et al., 20I2; Fungáçová et al., 20I4; Leroy, 20l4). Most of the previous studies on these issues have focused on the analysis of bank market power during normal times and there is no empirical evidence on how the level of bank market power resulting from the crisis may modify its impact on credit supply.

The results obtained in this research using a sample of 735 banks from 17 developed and developing countries during the 2003-20I2 period indicate that the higher level of monopoly power of banks during the GFC fostered a lower reduction in the amount of funds available to lend. This finding suggests that the increased level of market power is able to counteract the negative effect of the financial turmoil on credit supply. The results also show that these relationships are particularly important in the case of countries with less stringent restrictions on bank activities and less supervisory power.

Our results would have important policy implications for the relevance of bank market power as a channel through which periods of financial distress might affect bank lending. Moreover, they indicate the kind of regulations and supervisory mechanisms that might make any restructuring and consolidation processes resulting from crisis episodes more determinant during recovery from the crisis. 
The rest of the paper is organized as follows. Section 2 presents in more detail the theory behind our empirical study. Section 3 describes the sample and the methodology used in the empirical analysis. Section 4 presents the empirical results and robustness tests. Finally, Section 5 concludes.

\section{THEORETICAL BACKGROUND}

\section{I. Banking crises: real effects and effects on bank market power}

Our research relates to two important strands of the finance literature. First, it is related to studies analyzing the effects of banking crises on the economy. The flow of funds from banks to firms depends not only on potential borrowers' profitability and growth opportunities but also on adverse shocks affecting banks' ability to supply funds (Chava and Purnanandam, 20I I). The negative real effect of banking crises has traditionally been associated with a reduction in credit supply that blocks access to external capital for industrial firms (bank lending channel). Kroszner et al. (2007) find that the negative effect of banking crises on economic growth is particularly great in countries with more consolidated financial systems. Dell'Ariccia et al. (2008) show a more negative impact on economic growth in sectors that are more dependent on the services provided by banks when the latter suffer a sudden adverse shock that obliges them to reduce their credit supply. The relevance of the bank lending channel in the transmission of bank-specific shocks to economic growth is suggested by the extensive theoretical and empirical literature analyzing the relationship between bank capital and growth in loans (for a survey, see Sharpe (1995) and Gorton and Winton (2003)).

An extension of the evidence mentioned above would suggest a positive link between bank capital soundness, corporate investment, and economic growth through the lending channel. Focusing on the impact of banking crises on the amount of credit available to firms, Love et al. (2007) examines the relationship between bank credit and trade credit during and after crises in six emerging economies. They show that the provision of trade credit shrinks in the months and years after a banking crisis. The argument they provide is that the decline in aggregate trade credit ratios is driven by the reduced supply of trade credit that arises during a bank credit crunch. Considering the Russian crisis of fall 1998 as an exogenous shock to the US banking system, Chava and Purnanandam (20II) find that the banks that suffered most during the crisis, decreased their lending and increased the price of their loans in the post-crisis period. As a consequence, firms that relied more on this type of financing suffered larger losses during this period. Previously, Gatev et al. 
(2004) had shown that bank stocks lost over 10\% of market capitalization in late August and early September. FDIC' reports for 1998Q3 and 1998Q4 also indicate that the banking sector's financial health was under huge pressure at that time, resulting in a credit crunch for bank-dependent borrowers.

The reduction of credit provided by banks during the crisis years must have been related not only to the health of the bank in terms of capital, but also to the worsening of interbank market conditions. De Haan and van den End (2013) focus on the lending behavior of a sample of Dutch banks during the crisis. Their basic results show a reduction in wholesale lending as a consequence of the liquidity problems faced by banks. In a more recent paper, Kim and Sohn (20I7) provide a complete understanding of the relationship between both capital and liquidity constraints and banks' lending behavior. In a sample of US commercial banks, the authors show that bank capital exerts a significantly positive effect on lending only after large banks retain sufficient liquid assets².

Crises could also affect other characteristics of banking markets such as the degree of competition. From a theoretical point of view, the effect of banking crises on bank market power is unclear. In order to avoid new crisis episodes, banks may invest in safer but less profitable investment projects during post-crisis periods and this may lead to smaller margins and less market power (Detragiache et al., 2000). However, the restructuring of banking sectors during and after crisis periods involving the shutdown, merger or acquisition of failed banks may increase the market power of those that survive. Traditionally, the results of these intervention policies decrease the number of banks in the market (Laeven and Valencia, 2008, 20I2; Wheelock, 20II). The surviving banks are those that are less affected by inefficiencies and solvency problems than the banks that disappear. They can reduce costs and increase market share and margins after the crisis (Berger, 1995). Following these arguments and by using a sample of 64 countries and 66 episodes of banking crises during the 19892007 period, Cubillas and Suárez (2013) provide empirical evidence on the increase in bank market

\footnotetext{
I The Federal Deposit Insurance Corporation (FDIC) is a United States government corporation providing deposit insurance to depositors in US banks.

2 In order to clarify the specific relevance of both bank capital and liquidity on the reduction in credit supply during the GFC, we perform a robustness test on our international sample of banks. It shows that banks that had lower capital levels before the crisis experienced a larger reduction in their supply of funding. Our results, however, do not show any differential effect among banks that are more and less dependent on interbank market conditions.
} 
power consistent with the restructuring processes that often occur during episodes of financial distress.

\subsection{Bank market power and bank lending}

The second strand of the literature to which this research relates studies the effect of bank market power on credit availability and on cost of debt. The literature has traditionally posited that the influence of bank market structure on credit access for firms depends on the intensity of information asymmetries. In a market without information asymmetries, higher bank market power would result in higher prices for credit and lower credit availability (Klein, 197I). In presence of information asymmetries, the benefits for banks of holding close lending relationships with their borrowers may increase (Petersen and Rajan, 1994). Since higher banking market concentration facilitates the creation of close lending relationships between banks and younger firms, those entities enjoying high market power would be able to create close lending relationships and benefit from them when information asymmetries are relevant. The empirical evidence that uses bank concentration as the proxy of bank market power is mixed. Petersen and Rajan $(1994,1995)$ and Berlin and Mester (1999) show in the US market that firms in less concentrated credit markets are subject to greater financial constraints. However, D’Auria et al. (1999) for Italian firms and Degryse and Ongena (2005) for Belgian firms find that an increase in bank market concentration increases the cost of financing provided by banks. Cetorelli and Gambera (200I) find that the effect of bank concentration on economic growth varies across sectors. Although bank concentration generally has a negative effect on economic growth, it is positive in the case of industrial sectors that are most in need of external finance. The argument is that banking market concentration facilitates the creation of close lending relationships between banks and younger firms.

More recent studies have associated the relationship between bank market power and credit supply with ease of access for banks to alternative funding sources. Individual bank characteristics such as size, capitalization and liquidity are relevant to determine their access to financial markets. The structure of the banking sector may also affect funding choices. Banks with high market power should have relatively easy access to alternative sources of funding such as deposit certificates and interbank loans. In consequence, such banks will probably reduce their lending less because they have a greater ability to hedge against a temporary drop in margins or loan losses than banks for which it is more difficult to obtain funds from other sources. 
The influence of bank competition on the lending channel following monetary policy changes has been investigated by some authors. Adams and Amel (2005) analyze how banking sector structure, measured by the Herfindahl index, influences the credit supply to small businesses in aggregate regional US data for 1996-2002. They find that a concentrated bank structure hinders monetary policy transmission. Olivero et al. (20lla, b) study whether bank competition affects the bank lending channel in a sample of developing countries in Asia and Latin America from 1996 to 2006. They obtain opposing results depending on the proxy of competition used. Brissimis and Delis (2010) also provide some related evidence that heterogeneity at bank level, defined by differences in market power proxied by the Rosse-Panzar measure, may influence the response of banks to changes in monetary policy in a dataset mixing US and European banks from 1994 to 2007. Brissimis et al. (2012) analyze the impact of bank market power, measured by the Lerner index and the Boone indicator, on the reaction of banks in terms of both lending and risk-taking following monetary policy changes. For a large set of banks from 12 European countries and the US for the period 1997-2010, they find that bank competition expands the bank lending channel. The abovementioned study and other more recent ones contribute to this literature by examining a period including the 2007 financial crisis, allowing us to check for an impact of bank competition on the bank lending channel in normal times compared with more turbulent times (Gambacorta and Marques-Ibanez, 20II; Fungácová et al., 20I4; Leroy, 20I4). Schliephake (2016) examines the role played by bank market power on the tradeoff between the creation of a buffer to absorb losses and the rising cost of funding associated with capital regulation. The endogenous level of competition may be crucial for determining the efficiency of capital regulation in undercapitalized banking sectors, with excess capacities and correlated risks.

\subsection{Testable hypotheses}

Our paper establishes a link between the above-mentioned strands of the literature by analyzing how the recent GFC affected lending. We test this relationship globally and specifically through the changes in bank market power that occurred during this crisis episode. To our best knowledge, this question has not been analyzed. Obtaining empirical evidence in this respect would therefore be an important contribution to the literature.

According to the arguments and evidence provided by the previous literature (Kroszner et al., 2007; Dell'Ariccia et al., 2008; Fernández et al., 20I3b, 2018; among others), we would expect to find a lower growth rate of net bank loans in the years after the onset of the GFC, compared to the 
pre-crisis period. This would be an evidence of the lending channel acting to reduce bank loans due to shocks affecting the banks' balance sheet. Moreover, during banking crises, debtors usually have less incentives to invest and do not resort so much to banks for financing. Banks face a decrease of the average market quality, whereas adverse selection problems remain the same. Considering all these arguments, we can state our first hypothesis as follows:

HI: The growth rate of bank net loans is lower during the GFC years compared to the pre-crisis years.

In presence of asymmetric information, the benefits for banks of holding close lending relationships with their borrowers increase since they are able to produce and manage detailed information about them (Leland and Pyle, 1977; Campbell and Kracaw, 1980; Fama, 1985; Haubrich, 1989; Diamond, 1991). At the same time, there are higher switching costs for borrowers when trying to change the lending bank. In periods of crisis and high information asymmetries, banks only have incentives to lend to borrowers with whom they have a longstanding lending relationship. They prefer to allocate their funds to the better-known projects of relationship firms (Detragiache et al., 2000). A priori, they would not have incentives to lend to non-relationship borrowers.

During crises, lending relationships often collapse due to bank insolvency problems, in which case borrowers may be obliged to borrow from non-relationship banks. If they do not find a new bank to borrow from and get the funds that were previously provided by the relationship bank (now failed), borrowers may likely have to reduce their investments. Moreover, finding a new lender is more difficult in the less competitive banking market that emerges during and after a crisis episode.

This scenario would allow the banks that survive the crisis to enjoy an increased level of market power and to take advantage of a privileged position with respect to new potential borrowers. Since borrowers need to find a new lender quickly, banks can afford to require higher interest rates in loan operations. For this reason, in spite of the high information asymmetries, surviving entities would be willing to provide funds to borrowers coming from insolvent banks.

From the point of view of better access to market funding to hedge against possible loan losses, increased bank market power during the crisis may weaken the potential negative impact on the funds that banks are willing to lend. Following these arguments, we can state our second basic hypothesis as follows: 
H2: Banks whose market power increases during the GFC reduce the amount of credit less during these years.

In our analysis, we also control for differences across countries in terms of bank regulation and supervision. By controlling for these country-level features, we check the robustness of the results for the influence of the GFC on bank market power and credit supply. For instance, if bank market power is proxying for legal requirements that impede competition, then controlling for the regulatory and supervisory environment will drive out the significance of bank market power and make evident the reasons for potential significant coefficients of this to explain bank lending after the GFC. Finally, the use of a database composed by banks from 17 countries allows us to test whether and how certain regulatory features and supervisory mechanisms may make the effect of GFC through bank market power be more or less intense.

\section{DATA AND METHODOLOGY}

\section{I. Sample}

We use several main data sources. Bank-level information comes from the Fitch-IBCA Ltd. BankScope Database ${ }^{3}$. It contains comprehensive information on financial statements, ratings, and intelligence of banks across the globe. Whenever they are available, we use consolidated bank balance-sheet and income-statement data. We delete any unconsolidated entries of the group to avoid double counting and only include the unconsolidated data of banks for which this is the only type of information available in BankScope ${ }^{4}$.

Macroeconomic data are obtained from the International Financial Statistics of the International Monetary Fund (IMF). Variables measuring restrictions on bank activities, capital requirements and supervisory power come from the World Bank's surveys on Bank Regulation and Supervision by Barth et al. (2006, 2008, and 2013). Using the Laeven and Valencia (2012) database, we identify countries that experienced the current global financial crisis $(2007 / 2008)$ and the onset years of the

\footnotetext{
${ }^{3}$ Orbis Bank Focus since January I, 2017.

${ }^{4}$ All data are expressed in US dollars.
} 
crisis on each country. Our final sample is made up of an unbalanced panel for a maximum of 735 banks in 17 developed and developing countries during the 2003-20I2 period. This makes a total of 2,806 bank-year observations in our sample. Table I shows the list of countries, the inception date of the GFC on each country, and the number of banks and observations per country.

\section{INSERT TABLE I ABOUT HERE}

\subsection{Methodology}

Our empirical analysis considers that the GFC may affect bank market power and loans growth rate simultaneously and that changes in bank market power may be an indirect channel leading to changes in credit supply during this period. This analysis requires a procedure in two stages controlling for the potential endogeneity of both bank market power and loans growth and their potential simultaneous dependence on the crisis years. Therefore, we combine a Two Stage Least Squares $(2 S L S)$ procedure with panel data estimators.

We regress our proxy for banking lending on a dummy variable identifying the crisis period and on our measure of bank market power, controlling for other relevant factors at both bank- and country-level.

The structural equation to be estimated is:

$$
\begin{aligned}
& \Delta \mathrm{LOANS}_{\mathrm{i}, \mathrm{j}, \mathrm{t}}=\beta_{0}+\beta_{1} G F C_{j, t}+\beta_{2} \operatorname{LERNERp}_{i, j, t}+\beta_{3} \operatorname{LERNERp}_{i, j, t} * G F C_{j, t}+\beta_{4} B A N K_{i, j, t-1} \\
& +\beta_{5} \operatorname{COUNTRY} Y_{j, t}+\varphi_{t}+\mu_{i}+\varepsilon_{i, j, t}
\end{aligned}
$$

where $\mathrm{i}, \mathrm{j}, \mathrm{t}$ refer to the bank, country, and year, respectively. Dependent variable $\triangle$ LOANS $_{i j t}$ measures the annual variation of bank net total loans over the level of total assets in the previous year. $G F C_{j t}$ is a dummy variable that takes a value of one in the post-crisis period and zero in the pre-crisis one. We include additional bank- $\left(B A N K_{i j t}\right)$ and country- (COUNTRY ${ }_{j t}$ ) level control variables following, among others, Fungácová et al., (2014) or Leroy (2014). As bank-level control variables, we include asset size, liquidity, bank capital, the Z-score, the share of non-interest income in total bank income, and overhead costs. As country-level variables, we include the growth in GDP 
per capita and the dummy variable RECESSION $\mathrm{j}_{\mathrm{j} .} \cdot \varphi_{t}$ is the set of year dummies fixed effects to control for characteristics that are specific to each year. These specific controls allow us to capture any unobserved bank-invariant effects that are specific to each year and that are not included in the regression. $\mu_{i}$ is a bank-specific effect, which is assumed to be constant for bank $i$ over $t$, and $\varepsilon_{i j t}$ is a white-noise error term.

The Lerner index $\left(L E R N E R p_{i j t}\right)$ is the proxy variable for bank market power, negatively related with bank competition. In order to capture if the effect of the GFC on bank loans has been shaped by the different level of bank market power resulting from the crisis episode, we first calculate the predicted values of LERNER by estimating a first-stage regression in which the observed values of this variable are the dependent variable. The first-stage equation explaining bank market power $\left(\right.$ LERNER $\left._{\mathrm{ijt}}\right)$ is defined as follows:

$$
\begin{aligned}
\operatorname{LERNER}_{i, j, t}= & \alpha_{0}+\alpha_{1} \operatorname{GFC}_{j, t}+\alpha_{2} \text { BANK }_{i, j, t-1}+\alpha_{3} \text { FINFREE }_{j, t}+\alpha_{4} \operatorname{COUNTRY}_{j, t}+\varphi_{t}+\mu_{i} \\
& +\varepsilon_{i, j, t}
\end{aligned}
$$

As independent variables of the first-stage regression obtaining predicted values of LERNER we include all the explanatory variables in model $(I)$. This equation has its own predetermined variable or instrument: FINFREE, an index that measures the independence from government interference in the financial sector and the openness to foreign competition. It is provided by the Heritage Foundation. Instruments should affect the second-stage variable only through their effect on the first-stage endogenous variable. As it is always difficult to find suitable instruments, we motivate the choice of our instrument with economic and statistical arguments. From an economic point of view, state ownership of banks and other financial institutions reduces competition. In that sense, literature studying the link between financial liberalization and bank risk points out increases in bank competition following liberalization as a channel through which bank stability may be affected (Keeley, 1990; Hellmann et al., 2000; Repullo, 2004; Cubillas and González, 2014). So, we expect financial liberalization, proxied by FINFREE, to reduce bank market power. In addition to selecting our instrument based on economic arguments, we require it to pass relevance (correlation with the endogenous variable). We ensure that the first-stage Wald-test for the instrument is statistically significant, thereby indicating that it is relevant. 
The fitted values of LERNER (LERNER $p_{i j t}$ ) are used in the second stage as independent variable to estimate model (I). The 2SLS approach now allows us to separate different effects of the crisis in the LOANS equation. Therefore, coefficient $\beta_{1}$ of model (I) would indicate the direct effect of the GFC on the growth rate of bank loans regardless of changes in market power. Coefficient $\beta_{3}$ of the interaction between $L E R N E R p_{i j t}$ and $G F C_{j t}$ would capture the extent to which the GFC impacts loans growth through changes in bank market power.

We extend the basic model to find if differences in bank regulation and supervision lead to heterogeneity across countries regarding the effects of the GFC on the growth in bank loans also through the influence on bank market power. The extended model is specified as follows:

$$
\begin{aligned}
\operatorname{LLOANS}_{\mathrm{i}, \mathrm{j}, \mathrm{t}}= & \delta_{0}+\delta_{1} \operatorname{GFC}_{j, t}+\delta_{2} \operatorname{LERNERp}_{i, j, t}+\delta_{3} \operatorname{LERNERp}_{i, j, t} * G F C_{j, t} \\
& +\delta_{4} \operatorname{LERNERP}_{i, j, t} * G F C_{j, t} * \operatorname{REGSUP}_{j, t}+\delta_{5} R E G S U P_{j, t}+\delta_{6} B A N K_{i, j, t-1} \\
& +\delta_{7} \operatorname{COUNTRY}_{j, t}+\varphi_{t}+\mu_{i}+\varepsilon_{i, j, t}
\end{aligned}
$$

REGSUP $_{j, t}$ is a vector of variables identifying the main characteristics from the regulatory and supervisory environment. It comprises specific regulatory variables identifying the extent to which non-traditional banking activities are allowed in each country (RESTRICTI, RESTRICT2, and OWN), the extent to which bank capital is regulated (CAPREG), and the extent to which public authorities and private investors supervise the banks' behavior (SUPPOW and MONITOR, respectively). We are specifically interested in coefficient $\delta_{4}$ since it captures how different countrylevel characteristics influence the relationship between the crisis and credit supply through changes in bank market power.

\subsection{Variables}

\subsection{Key variables: GFC, bank market power and loans growth}


To capture the effect of the Global Financial Crisis on credit supply, we define our main dummy variable (GFC) that takes a value of one for the years in the post-crisis period and zero during the pre-crisis period. The inception year of the crisis in each country and one year more are omitted in the regressions to avoid confounding effects ${ }^{5}$. This dummy variable allows us to identify the differential effect of bank market power and bank lending between the post-crisis and the pre-crisis period.

We use the Lerner index (LERNER) as a proxy of bank market power, inversely related to bank competition. The Lerner index has been widely and recently used in the banking sector as an indicator of the degree of market power (Beck et al., 2013; Fernández et al., 2013a; Cubillas and González, 2014, among others). It defines the difference between price (interest rate) and marginal cost expressed as a percentage of price. It assumes that the divergence between product price and marginal cost of production is the essence of monopoly power ${ }^{6}$. The Lerner index takes value zero in the case of perfect competition. It takes value one under perfect monopoly. We estimate a single indicator of the Lerner index using the same procedure as Maudos and Fernández de Guevara (2004). Algebraically the Lerner index for each bank $i$ is calculated as follows:

$$
\operatorname{LERNER}_{i j t}=\frac{p_{i j t}-M C_{i j t}}{p_{i j t}}
$$

where the product price $p_{i j t}$ is the total financial and operating income (interest income + commission income + fee income + trading income + total operating income) divided by total assets of bank $i$ from country $j$ in period $t . M C_{i j t}$ is the marginal cost for bank $i$ from country $j$ in period $t$ of producing an additional unit of output. The marginal cost is derived from a translog cost

\footnotetext{
${ }^{5}$ The inception date of the crisis is 2007 for United States and United Kingdom; 2009 for Nigeria; and 2008 for the rest of countries, as reported by the Laeven and Valencia (20I2) dataset. We check that the results do not vary when we define the crisis variable as a dummy that takes value I during the post-crisis period, 0 during the pre-crisis years and missing values during the onset of the crisis and the two following years.

${ }^{6}$ We check the robustness of our results using an alternative measure of bank market power. It allows us to avoid the implicit assumption of full efficiency that characterizes the conventional approach of Lerner index. For its estimation, we follow Koetter et al. (20I2). A more detailed explanation of the construction of this adjusted Lerner index is provided in Appendix A. Results are presented in the robustness checks section.
} 
function. Finally, we use the annual growth rate of bank net loans over the level of assets in the previous year to measure the variation in bank credit supply ( $\Delta$ LOANS).

\subsubsection{Control variables}

We include bank-level and macroeconomic variables as control variables. Bank-specific characteristics used are the asset size (SIZE), liquidity ratio (LIQUIDITY), capitalization (CAPITAL), level of risk (ZSCORE), share of non-interest income in total bank income (NONINTEREST), and overhead costs (OVERHEAD).

Bank size, liquidity, and capitalization ratios are three bank-level characteristics connected to bank lending behavior since they are relevant to determine its access to financial markets and may influence the amount of credit available to lend (Kashyap and Stein, 2000; Kishan and Opiela, 2000; Altunbas et al., 2002; Van den Heuvel, 2002; Ehrmann et al., 2003; Gambarcorta, 2005; Altunbas et al., 2009; Fungácová et al., 20I4; Leroy, 20I4). SIZE is defined as the natural logarithm of total bank assets. LIQUIDITY is the share of liquid assets in total assets. CAPITAL is the bank's own Tier 2 capital-to-total assets ratio. It is expected that small, illiquid and undercapitalized banks cut more their credit since they may have more difficulties to compensate losses in lending with gains resulting from the access to financial markets and different sources of funds. However, high levels of liquidity may also allow a bank to draw on its own liquid funds instead of relying on the market. Therefore, it is important to control for these three bank characteristics.

Beyond size, liquidity, and capitalization, other bank-level factors could influence the lending. According to Altunbas et al. (2010), the risk channel must also be taken into account when analyzing the effects of a monetary shock on bank credit supply. A less risky bank will have a greater ability to refinance itself in the market and will, therefore, be less affected by a shock. We use the Z-score of a bank (ZSCORE) as a proxy for bank risk. Z-score equals the return on assets plus the capital asset ratio divided by the standard deviation of asset returns. A 4-year moving window is used to estimate standard deviations for each bank in each year. A higher Z-score indicates that a bank is more stable because it is inversely related to the probability of bank insolvency. Because the Z-score is highly skewed, we use the natural logarithm of the Z-score, which is normally distributed. Laeven and Levine (2009) and Hadad et al. (20I I), among others, have used the Zscore as a proxy for bank insolvency risk. Loutskina and Strahan (2009), Altunbas et al. (2009) and Gambacorta and Marques-lbanez (20II) show how securitization activities reduce the effectiveness 
of monetary shocks. Similarly, the share of non-interest activities would be a factor influencing crisis transmission to loans supply. We control for this aspect through the non-interest income-to-total revenue ratio (NONINTEREST). Finally, we control for the degree of bank efficiency by including OVERHEAD as explanatory variable. OVERHEAD is defined as non-interest bank expenses (personnel expenses and other non-interest expenses) divided by total assets. Differences in this variable may capture differences in employment or wage levels as well as banks' product mixes and quality of service. Higher expenditures may be associated with less efficient banks.

The granted loans do not depend only on elements relating to the supply but also to the demand of credit. Banking crisis episodes affect the balance-sheet structure of banks, causing changes in both the supply and demand for bank loans. During distress episodes, firms usually invest less and do not resort so much to banks for borrowing. Moreover, due to the economic downturn, banks might find less profitable customers due to the decrease in the average market quality, whereas adverse selection problems remain the same. Collateral might become less valuable and, therefore, customers less attractive for banks. All these arguments justify the distinction between potential supply and demand effects, although it is difficult to carry out in empirical studies. Following Kashyap and Stein (1995) among others, the literature has opted for the use of disaggregated data at bank-level. They assume that banks face identical loans demand. So, if changes in lending differ across banks, is because different types of banks adjust their supplies of credit in a different way.

The assumption of homogenous loan demand could be relaxed with the availability of loan-level data (Khwaja and Mian, 2008; Jimenez et al., 20I2). However, loan-level data are not available for our international sample of banks. Therefore, to take into account the potential demand effects in our empirical analysis, we proceed in a double way. First, following previous studies, in all of the estimates, we include the growth in GDP per capita as a macroeconomic control variable $(\triangle \mathrm{GDP} p \mathrm{C})$. Second, we define a dummy variable identifying the economic recessions years on each country. RECESSION takes the value $I$ if country $j$ is experiencing a recession episode in period $t$. Otherwise, it takes the value 0 . Economic recessions may also affect the amount of bank loans, as bank-dependent borrowers are hurt disproportionally more during recessions (Braun and Larrain, 2005). Bank insolvency and/or liquidity problems may also spike during economic downturns and the estimations simply reflect this fact. If bank instability spikes during economic downturns and we do not control for recessions, changes in the amount of loans may be capturing the effects of business cycle rather than causality from banks to the real economic sector. For this reason, we control for recessions to avoid confounding effects from the economic cycle. We identify 
recessions in each country following the methodology applied by Braun and Larrain (2005) ${ }^{7}$.

Panel A and Panel B of Table 2 report descriptive statistics (mean, median, standard deviation, minimum, maximum, and $\mathrm{VIF}^{8}$ ) and correlations of our main variables, respectively.

\section{INSERT TABLE 2 ABOUT HERE}

\subsubsection{Bank regulation and supervision}

To capture the influence of bank regulatory and supervisory characteristics, we use six different variables. The first is whether banks are allowed to take part in activities that generate non-interest income. This variable indicates whether bank activities in the securities, insurance, real estate markets, and participation on the ownership and control of non-financial firms are: (I) unrestricted, (2) permitted, (3) restricted, or (4) prohibited. This indicator, theoretically, can range from a minimum value of 4 to a maximum value of 16 , where higher values indicate more restrictions on bank activities (RESTRICTI).

Second, we consider a regulatory index excluding the specific legal restrictions on bank ownership and control of non-financial firms (RESTRICT2). We exclude this legal restriction in order to analyze if the effects on the growth rate of bank loans remains after excluding regulations on the mix between banking and commerce. This variable can range, in theory, from a minimum value of 3 to a maximum value of 12 . It is constructed giving value I, 2, 3, or 4 if the banks activities in the securities, insurance, real estate markets are (I) unrestricted, (2) permitted, (3) restricted, or (4) prohibited. Therefore, higher values in this variable indicate more stringent regulation on nontraditional banking activities.

Third, we consider the extent to which bank participation on the ownership and control of nonfinancial firms is regulated (OWN). This variable can range, in theory, from a minimum value of $I$ to a maximum value of 4 . It is constructed giving value I, 2, 3, or 4 if the banks participation as an

\footnotetext{
${ }^{7}$ A more detailed explanation of the construction of RECESSION dummy is provided in Appendix $B$.

${ }^{8}$ A common rule of thumb is that if VIF > 10 then multicollinearity problems are relevant (See Gujarati, 2003; Beck et al., 2006). In our case, only the variable SIZE (defined as the natural logarithm of total assets) presents a VIF value higher than 10 . This result could be due to the fact that LIQUIDITY, CAPITAL, ZSCORE, and OVERHEAD are explanatory variables constructed by using the total assets as reference variable.
} 
owner of a non-financial firm is (I) unrestricted, (2) permitted, (3) restricted, or (4) prohibited.

We also introduce an index that measures the stringency of capital regulatory (CAPREG). It captures, among other aspects, whether there are explicit regulatory requirements regarding the amount of capital that a bank must have, whether certain funds may be used to initially capitalize a bank and whether they are officially verified. This variable can range, in theory, from a minimum value of 0 to a maximum of 9 , with a higher value indicating greater stringency.

We include two variables indicating the characteristics of each country in terms of supervision. First, we include an index of the power of the commercial bank supervisory agency (SUPPOW). This index captures the power of supervisors to undertake prompt corrective action, to restructure and reorganize troubled banks, and to declare a deeply troubled bank insolvent. Higher values indicate more official supervisory power. Second, we use an index measuring the extent of private-sector monitoring (MONITOR). This index captures whether a certified audit is required; the percent of 10 biggest banks rated by international rating agencies; whether there is an explicit deposit insurance scheme; and aspects related to the bank accounting and disclosure requirements. Higher values of this index indicate more private oversight. Information on the above regulatory and supervisory variables comes from the World Bank's Bank Regulation and Supervision database (Barth et al., 2006, 2008, and 2013).

\section{EMPIRICAL RESULTS}

\section{I. GFC and bank market power}

In this section, we firstly examine how the recent episode of global financial crisis affected the level of bank market power and if this effect has been different across banks and across countries depending on bank-level characteristics and on bank regulation and supervision.

Table 3 presents results for the set of first stage equations explaining how the GFC impacts the individual Lerner index. Columns (I) and (2) show results for random and fixed effects panel data regressions, respectively. According to the Hausman test, the use of fixed effects is more appropriate than the random effects estimates. In columns (3) to (8) we check if the effect of the GFC on bank market power is different across banks. We report results for fixed effects panel data 
specifications when we introduce an interaction term between the GFC dummy and the different bank-level characteristics used as control variables. In all specifications, we obtain a positive and statistically significant coefficient for the GFC dummy variable. Only in column (4) the GFC does not affect significantly the Lerner index. This finding indicates that there is, on average, a reduction of bank competition after the onset of the crisis. FINFREE presents a negative and significant coefficient in all the alternative model specifications. According to our intuition, this result would indicate that a high level of financial freedom promotes competition in the banking market.

Coefficients for SIZE show that this characteristic is not statistically significant for explaining market power in banks of our sample. Only in column (I), when we apply a random effects panel data approach, the coefficient for SIZE is positive and significant, indicating that the larger the bank is, the greater market power it has. LIQUIDITY and OVERHEAD variables always show a negative and statistically significant coefficient, indicating that a lower proportion of liquid assets and a high level of efficiency increase the bank market power. Coefficients of ZSCORE and NONINTEREST are positive and significant. Only in column (7) NONINTEREST is positive but not statistically significant at conventional levels. This indicates that the lower the level of bank risk and higher the relevance of non-interest activities, the higher the bank market power. Coefficients for bank capital (CAPITAL) are negative in almost all estimations but only statistically significant at 10 percent level in column (6). Growth in GDP per capita is not statistically significant at conventional levels. The dummy variable that identifies the recession years (RECESSION) presents a positive and statistically significant coefficient indicating that the recession years promote increases in bank market power. Regarding interaction terms between the GFC variable and the different bank characteristics, we obtain positive and statistically significant coefficients in the case of LIQUIDITY, ZSCORE and NONINTEREST. These results indicate that the increase in market power during the crisis has been stronger in more liquid and stable banks and in the case of banks with higher level of noninterest income.

\section{INSERT TABLE 3 ABOUT HERE}

Table 4 reports the results for equations explaining if the impact of the GFC on the Lerner index is different depending on regulatory and supervisory characteristics of the banking system of each 
country9. In five out of the six specifications, we obtain negative and statistically significant interaction terms indicating that the increase in bank market power is lower in countries where the regulation and supervision on banking system is stricter. This finding is consistent with the fact that a stringent level of regulation and supervision does not favor competition. Therefore, if the market power of banks is already high in these countries, there is a smaller margin to increase it. Moreover, in these more regulated and supervised banking systems, entities would not have taken so high levels of risk and restructuring processes would not have been so required. Control variables show similar coefficients to those obtained in Table $3^{10}$.

\section{INSERT TABLE 4 ABOUT HERE}

\subsection{GFC, bank market power, and loans growth}

Once we have examined how the GFC affected bank market power, Table 5 presents the results for equations explaining loans growth in two different Panels with alternative specifications of the empirical model. Panel A reports the results of analyzing the direct effect of the global financial crisis on bank credit supply. The coefficient of the GFC dummy variable captures how lending varies in the years of the crisis due to channels different from changes in bank market power. Panel B shows both the direct effect of the crisis on bank lending (coefficient of GFC) and the indirect effect that takes place through the changes in bank market power occurred during the crisis (coefficient of LERNERP*GFC). Columns (I) and (3) report the results of random effects estimations. Columns (2) and (4) report the results of fixed effects estimations. The Wald test obtained in the first stage estimation confirms the significance and suitability of the instrument used to explain LERNER in the first stage (FINFREE). Results of the Hausman test indicate that the use of fixed effects is more appropriate".

\footnotetext{
${ }^{9}$ Alternatively, in this point of the analysis, we have also considered the value that each indicator of bank regulation and supervision takes in the year before the crisis inception date to make it exogenous to the period of the financial crisis. The results are similar to those showed in Table 4 and are available from the authors upon request.

${ }^{10}$ Notice that when we consider the regulatory and supervisory variables, the number of countries is reduced to 16 . This is due to the absence of information on these variables for Mongolia in all the years of the sample period. Additionally, the number of banks varies between 721,722 and 723 depending on the variable. This is due to the absence of information on these variables for some countries in some specific years of the sample period.

"Following the result of the Hausman test, we apply the fixed effects panel data approach for the rest of the empirical analysis. Results obtained through random effects estimates are similar to those shown in the paper and are available from the authors upon request.
} 
According to the theoretical expectations and to our first hypothesis, in all these estimations we obtain a negative and significant coefficient for the GFC dummy variable indicating that the growth rate of bank net loans is lower during the post-crisis period than during the pre-crisis years. This result confirms the negative effects of the crisis on credit supply (Gatev et al., 2004; Love et al., 2007; Chava and Purnanandam, 20II) and the relevance of lending as a channel through which banking crises negatively impact real economy (Kroszner et al., 2007; Dell'Ariccia et al., 2008; Fernández et al., 20l3b).

As Panel B shows, we obtain positive and significant coefficients for the interaction term between the predicted value of the Lerner index and GFC (LERNERP*GFC). This result indicates that the negative impact of the crisis on the amount of loans granted by banks is counteracted by increases in the level of market power that banks experience, on average, during the years of crisis. This positive effect of the bank market power is also economically significant. Using, for instance, the results in column (3) of Table 5, an increase of one standard deviation in LERNER (0.342I) during the crisis, would increase the annual growth rate of bank net loans by 3.3 times its standard deviation. It confirms our hypothesis about the positive role of the increased level of bank market power after the onset crisis as it helps to reduce less the amount of credit available to lend during these years $(\mathrm{H} 2)$. This result is consistent with studies associating the relationship between bank market power and credit supply with the ease in accessing for banks to alternative sources of funding. If banks with higher market power have greater access to the financial markets and under better conditions, they could hedge against losses in the lending activities through by using funds from other sources. As a consequence, they will not need to reduce the amount of credit to lend (Gambacorta and Marques-Ibanez, 20II; Brissimis et al., 20I2; Fungácová et al., 20I4; Leroy, 20I4).

Moreover, our result could suggest that stronger market power of surviving banks is associated with more incentives to provide funds not only to relationship debtors, but also to non-relationship borrowers because of beneficial credit conditions. If during the crisis, the relationship bank goes bankrupt -due to insolvency problems from the bank's side- some of its borrowers are obliged to borrow from non-relationship banks to keep their investments. Since they need to find a new lender quickly, banks can afford to require higher interest rates in loan operations. Therefore, in spite of the high information asymmetries, surviving entities -enjoying a higher level of market power- would be willing to provide funds to those non-relationship borrowers. 
Regarding the control variables, SIZE presents negative and statistically significant coefficients in all estimations, indicating that banks' size is negatively related to loans growth. We expected that this effect would be present only once the crisis takes place. Since large banks expect to receive government support in case of financial problems, they would have assumed higher levels of risk and need to reduce credit more than other banks. LIQUIDITY is only significant in columns (I) and (3) where we can see that it is positively associated to the growth rate of banks loans. This may be due to the fact that banks with high levels of liquidity draw on its own liquid funds instead of relying on the market. CAPITAL is statistically significant in columns (I), (3), and (4). The positive sign of the coefficient is consistent with the expectation that undercapitalized banks cut more their credit since they may have more difficulties to compensate losses in lending with gains resulting from the access to financial markets and different sources of funds. OVERHEAD is positively related to loans growth as our results show in all columns. We interpret this result as that those more efficient banks are also more prudent in loan lending. In the same line, the negative and significant coefficients for the ZSCORE in three of the four specifications, suggest that the lower the bank risk, the lower the growth rate of bank loans. The proxy measuring the non-interest income over total income of the bank (NONINTEREST) shows negative and statistically significant coefficients in all the estimations of Table 5. $\triangle \mathrm{GDPpC}$ presents negative signs for its coefficients in columns (I), (2) and (4), suggesting that, precisely in countries with higher economic growth, a higher reduction of bank credit took place. The coefficients for the RECESSION dummy do not present a statistically significant effect in any of the estimates shown in Table 5.

\section{INSERT TABLE 5 ABOUT HERE}

\subsection{GFC, bank market power, and loans growth: Influence of bank regulation and supervision}

In this section, we examine the influence of bank regulation and supervision on the role played by bank market power to shape the impact of the global financial crisis on loans growth. Differences in the requirements and enforcement of bank regulation and supervision across countries may affect potential changes in bank market power during a banking crisis and, therefore, the amount of funds to be lent by banks. To test this, we analyze how the variables proxying for bank regulation and supervision interact with the term LERNERP*GFC to shape their influence on loans growth. 
In Table 6 we present the results examining how the crisis influences loans growth through changes in bank market power by controlling for alternative measures of bank regulation and supervision. Specifically, regulatory variables have to do with the regulation on non-traditional banking activities (RESTRICTI, RESTRICT2, and OWN), and with the stringency of regulation on bank capital (CAPREG). In terms of supervision, we consider the supervisory power exercised by official authorities and private investors (SUPPOW and MONITOR). To carry out this analysis, we refer to the model specification (3) in which we introduce a triple interaction term between the predicted value of the Lerner index, the GFC dummy and the variable from the regulatory and supervisory environment (LERNERP*GFC*REGSUP).

Results shown in Table 6 indicate that the negative and significant coefficient of the GFC dummy variable remains invariant. We also find again a positive coefficient for LERNERP*GFC indicating that the crisis affects loans growth less negatively through the increase in bank market power occurred during these years. These effects are statistically significant at conventional levels in all estimates.

We obtain negative coefficients for the triple interaction terms between the predicted value of the Lerner index, the GFC dummy variable and the measures of the regulation on non-traditional banking activities in columns (I), (2) and (3). This finding suggests that the most positive effect of changes in bank market power during the crisis takes place in countries characterized by less stringent restrictions on non-traditional banking activities. In line with our reasoning, in those countries where bank regulation is not an impediment to participate in non-traditional activities, banks with higher market power and therefore, easier access to alternative sources of funding, do not have incentives to cut their lending as much as if the legal restrictions on non-traditional banking activities were more stringent. On the other hand, these results are consistent with those obtained in Table 4, where we show that the increase in bank market power after the onset of the crisis is greater in countries with less stringent restrictions on bank activities. If in these environments, the surviving banks acquire a higher level of market power, they can bargain lending conditions in their favor with other new borrowers coming from failed banks. Therefore, they do not have incentives to reduce credit as much as banks in countries with more stringent regulation on bank activities.

The negative and statistically significant coefficient for the interaction term LERNERP*GFC*SUPPOW in column (5) suggests that the most positive effect of changes in bank 
market power during the crisis takes place in countries characterized by a lower level of official supervisory power. As banks from countries with stronger and relevant official and private supervisory mechanisms would not have assumed so much risk during the pre-crisis period, the reduction in credit during the years of crisis would be less important. By analyzing a sample of 50 advanced and emerging market economies, Fratzscher et al. (2016) conclude that a strengthening of supervisory independence helped to reduce the decline in domestic credit after the crisis and improved the stability of banks. In this sense, the positive effect of the bank market power would be less relevant since there is a lower margin to mitigate the negative impact on the credit supply. Additionally, in countries characterized by a strong official supervisory power, even those banks whose market power is high, would have less freedom to access market funding to hedge against losses in lending.

We do not obtain a statistically significant coefficient at conventional levels for the triple interaction term when the regulatory variable considered is CAPREG (column (4)). This result suggests that the stringency of capital regulation is not decisive in the role that bank market power plays in counteracting the negative impact of the crisis on credit supply. We think that at this point, there could be two opposing effects. On one hand, banks from countries with more stringent capital requirements would be better ready to access to market funding and have a greater ability to hedge against losses in lending. As a consequence, they do not have many incentives to reduce their credit. On the other hand, however, results in Table 4 indicated a lower increase in the bank market power in countries with a more stringent capital regulation. As only those banks with high market power, can bargain lending conditions in their favor with new borrowers, banks in these countries could have more incentives to cut lending. These possible opposing effects could explain the non-significant coefficient for the triple interaction term. We interpret in the same way the non-significant coefficient obtained in column (6) for the term LERNERP*GFC*MONITOR.

\section{INSERT TABLE 6 ABOUT HERE}

\subsection{Robustness Tests}

In previous sections, we have shown that the GFC negatively affected growth in bank loans but this effect was less negative in banks that experienced a greater increase in market power as a result of the crisis. Moreover, the result was not homogeneous across countries and it depended on the features of the regulatory and supervisory environment. In further analyses, we check the additional robustness of our basic results. First, we consider an alternative measure of bank market power, 
based on Koetter et al. (2012), that eliminates the conventional assumption of full efficiency in the traditional Lerner index estimation. Second, we study regulatory bank capital and liquidity restrictions as the channels through which the reduction in bank loans takes place during the crisis years. Third, we address potential reverse causalities between bank market power and lending relationships.

\subsection{Alternative measure of bank market power}

In our first robustness test, we check that the results do not change when we use an alternative proxy of bank market power. Specifically, we estimate an adjusted Lerner index to avoid the implicit assumption of full efficiency that characterizes the conventional Lerner index approach. Banks rarely operate under perfect efficiency. In fact, their operating costs vary over time and depending on the economic environment in which they operate (Chaffai et al., 200I).

After a global financial crisis like the recent one, bank efficiency levels likely change because of structural changes, new lending methods, changes in the business model or changes in human capital provision. Hence, differences across countries (or changes over time) in Lerner indices may also be due to differences (or changes) in non-competitive factors. In consequence, it could be important to test our results by using a proxy of bank market power that allows us to eliminate the assumption of full efficiency.

To do this, we apply a similar methodology to the one used by Koetter at al. (20I2). These authors propose a simple adjustment to Lerner indices to account for the possibility of foregone rents to test the "quiet life" hypothesis that postulates a negative correlation between market power and efficiency. According to this hypothesis, the higher the market power, the lower the effort made by managers to maximize operating efficiency. We think this is an appropriate way to estimate bank market power and show the robustness of our results, thus eliminating concern regarding the assumption of perfect efficiency. Appendix A describes the detailed calculation of this adjusted Lerner index.

We check that our basic results do not change when we use this adjusted Lerner index. Table 7 is a replica of our main table of results (Table 5) where we report the regressions analyzing both the direct effect of the crisis on bank lending and the indirect effect caused by the changes in bank market power that occurred during the crisis. As in Table 5, we obtain a negative and significant 
coefficient for the GFC dummy variable in all estimations, indicating that the growth rate of net bank loans is lower after the onset of the crisis period than during the pre-crisis years. We also obtain positive and significant coefficients for the interaction term between the predicted value of the adjusted Lerner index and GFC (showed in Panel B). This result indicates that the negative impact of the crisis on the amount of loans granted by banks is counteracted by increases in the level of market power that banks experience, on average, during the crisis years. By using a proxy of bank market power that avoids the implicit assumption of full efficiency, our second hypothesis about the positive role of the increased level of bank market power during the crisis is confirmed.

A shortcoming of this Lerner approach, however, is the reduction in the number of banks that are considered in the analysis. With the conventional Lerner index proxy, regressions include 2,806 observations and 735 banks. With the adjusted Lerner index, these are reduced to $2,48 \mathrm{I}$ and 670 , respectively. The number of banks is reduced to $65 \mathrm{I}$ when we examine the influence of certain regulatory and supervisory variables on the role played by bank market power to reduce the negative impact of the crisis on growth in loans.

\section{INSERT TABLE 7 ABOUT HERE}

\subsubsection{Regulatory bank capital and liquidity}

In our second robustness test we analyze in greater depth the bank-side reasons why the crisis episode negatively affected growth in bank loans. Due to losses experienced during the crisis, bank capital regulation became binding. As banks are unlikely to be able to issue new equity in times of crisis, they might be forced to cut back lending (capital regulation channel). Moreover, the banks for which it is most difficult to get funding from alternative liquidity sources (i.e. customer deposits) can be expected to rely on the interbank market the most. Consequently, such banks might be obliged to reduce lending because of worse interbank market conditions during the crisis period (liquidity channel). As a result, banks probably become more adverse to risk and, during the crisis, prefer to invest in safer securities rather than risky loans. Therefore, in order to reach the required capital levels and to guarantee the most appropriate levels of liquid assets on their balance sheets, banks might be forced to cut back lending during and after a period of financial distress. The recent paper by Thakor (2018) argues that the global financial crisis stemmed from an insolvency risk crisis in financial institutions and not from liquidity crisis episodes. Therefore, the author states that post- 
crisis regulatory reform should focus on increasing capital requirements instead of constraining the asset transformation and liquidity creation roles of banks.

We try to methodologically disentangle the specific channel, i.e. capital regulation channel and liquidity channel, through which the GFC provoked a reduction in the provision of credit by identifying the banks which, after the onset of the crisis, might be particularly affected by more stringent regulatory bank capital and worse interbank market conditions. First, we assume that financial entities that are identified as undercapitalized banks during the years prior to the crisis would have been forced to make greater cuts in credit when regulation on bank capital became binding. This would be evidence that the capital regulation channel offers a relevant explanation for the reduction in the provision of bank loans. Second, in terms of the liquidity channel, we identify the banks that, due to their level of liquid assets before the crisis, would find it difficult to comply with the new liquidity standards established by the Basel III Accord in the following years. We also identify the banks that are most dependent on the interbank market since it is difficult for them to get financing from other liquidity sources, such as customer deposits. If the liquidity channel works to explain the reduction in credit supply, we can expect to observe that banks with lower liquidity ratios and lower levels of customer deposits before the crisis reduce the provision of loans the most during the financial turmoil.

In order to classify our banks according to their level of capital and liquidity, we proceed as follows. We define two dummy variables: REGCAPITAL and LIQUIDASSETS. The first takes value $I$ if the TIER2 capital ratio of each bank is, at least, equal to $8 \%$ (non-constrained banks), and 0 otherwise (constrained banks). The second takes value $I$ in the case of banks whose liquid assets-to-liquid liabilities ratio is larger than $\mathrm{I}$ (non-constrained banks) and 0 otherwise (constrained banks). Alternatively to the LIQUIDASSETS ratio, we define the customer deposits-to-total debt ratio (CUSTOMDEBT). This variable takes value I for banks whose CUSTOMDEBT ratio is above the 10th percentile, and 0 otherwise. The intuition is that banks with less customer deposits on their balance sheet would rely on getting funds from the interbank market the most (constrained banks). However, banks with higher ratios for customer deposits-to-total debt, would be less affected by potential liquidity shocks (non-constrained banks). The three dummy variables refer to 2006 data in order to avoid potential confounding effects from the crisis episode.

Results obtained are shown in Table 8. Columns (I) and (2) in Panel A present the results obtained for the subsamples of banks with and without constraints in terms of regulatory bank capital. In 
Panel $B$ we focus on the subsamples of banks with and without liquidity constraints defined in terms of both the LIQUIDASSETS (columns (3) and (4)). Panel $C$ shows the results obtained across banks with low and high levels of the CUSTOMDEBT ratio (columns (5) and (6), respectively). According to the results presented in Panel A we can state that the most negative effect of the GFC on growth in bank loans took place in the subsample of banks with a TIER 2 capital ratio below $8 \%$ in 2006. This result suggests that the GFC did not impact the credit supply of all banks equally, but particularly affected the banks that were subject to greater constraints when regulation on bank capital became binding. In terms of the different subsamples of banks according to their liquidity conditions, we do not find any statistically significant result of the GFC, when using either the LIQUIDASSETS ratio or the CUSTOMDEBT ratio. These results seem to be consistent with the arguments provided by Thakor (2018) and referred to above ${ }^{12}$.

\section{INSERT TABLE 8 ABOUT HERE}

\subsubsection{Bank market power and lending relationships: reverse causality}

The literature has traditionally posited that the benefits for banks of holding close lending relationships with their borrowers would increase in the presence of asymmetric information since they have the ability to produce and manage detailed information about borrowers (Leland and Pyle, 1977; Campbell and Kracaw, 1980; Fama, 1985; Haubrich, 1989; Diamond, 199I). Moreover, higher banking market concentration facilitates the creation of close lending relationships between banks and younger firms (D'Auria et al. 1999; Cetorelli and Gambera, 200I; Degryse and Ongena, 2005). Therefore, banks enjoying high market power would be able to create close lending relationships and benefit from them during episodes of crisis, when information asymmetries become more important. However, a problem of reverse causality might arise. The increased level of bank market power that we observe after the onset of the crisis might result from existing lending relationships. Banks with valuable relationships may benefit from them, or exploit them in times of greater asymmetric information, leading to higher market power. In our case, this would

\footnotetext{
12 Notice that the variable proxying for bank market power in these estimates is the observed value of the Lerner index instead of its predicted value. Therefore, this variable does not capture the simultaneous effect of the GFC on the market power of each bank.
} 
be an additional argument to explain the increase in the market power that surviving banks experience in the years of crisis. In fact, these banks have not yet had time to establish long lending relationships, so they cannot benefit from them. Incentives for not cutting lending would be related to the beneficial credit conditions that they can obtain by bargaining with borrowers coming from insolvent banks.

However, we think it is important to empirically examine this potential reverse causality problem. Previous papers dealing with the relevance of close lending relationships use disaggregated loan- and firm-level data. In this paper, we attempt to address this question by trying to identify banks or countries in which, following previous literature, lending relationships are more frequently found (see La Porta et al., 1997, 1998; Boot, 2000; Dell' Ariccia and Marquez, 2004; Elyasiani and Goldberg, 2004; Bharath et al., 2007; Fernández et al. 2010, among others). It seems reasonable to argue that banks mainly focused on traditional banking activities should promote investment in the acquisition of soft information about clients, in which case we should observe that lending relationships are more likely in banks with higher levels of specialization in credits and deposits. If we focus on size, previous literature has shown that lending relationships are more important in small banks. Regarding institutional quality, in countries with weak legal systems and less developed institutional infrastructure, long-term lending relationships would be especially helpful in solving adverse selection and moral hazard problems between firms and banks.

Therefore, ceteris paribus, if causality runs from lending relationships to bank market power, we should observe a more substantial increase in market power during the crisis in the case of: (I) more specialized banks or those that focus on traditional banking activities; (2) smaller banks, and (3) countries with lower levels of institutional quality. Results of these tests are already partially reported in Table 3 through the interaction terms between the GFC variable and the variables NONINTEREST and SIZE, respectively. We obtain a positive and statistically significant coefficient in the case of NONINTEREST which indicates that the increase in market power during the crisis was stronger in banks with a higher level of non-interest income or that were less focused on traditional activities, and where close lending relationships are less likely. We do not obtain a statistically significant coefficient for interaction term when the variable considered is SIZE. Therefore, we cannot state that banks in which closer lending relationships are expected can attain higher market power by exploiting them in times of increased asymmetric information. 
Likewise, if causality runs from lending relationships to bank market power, we should observe that the latter is more relevant for moderating the reduction in bank credit supply during the crisis in the case of: (I) more specialized banks or those that focus on traditional banking activities; (2) smaller banks, and (3) countries with a lower institutional quality.

In Table 9 we present the results obtained when we split our international sample of banks around the median values of NONINTEREST and SIZE (PANELS A and B, respectively). In Panel C we split the sample around the 75th percentile of the variable proxying for the level of institutional quality of each country: Rule of Law, one of the World Governance Indicators, periodically computed by the World Bank. We run our basic equation (I) testing if the impact of the GFC on growth in loans is different across banks depending on the increased level of bank market power. We obtain a positive and statistically significant coefficient for the interaction term GFC*LERNER in column (I). The interaction term GFC*LERNER does not present a statistically significant result in column (2). These results indicate that the moderator effect of bank market power is stronger in banks that are more involved in non-traditional banking activities and in which close lending relationships are expected to be less important. In columns (3) to (6) we always obtain a positive coefficient for GFC*LERNER. This result suggests that bank market power shaped the impact of the GFC on growth in loans irrespectively of bank size and countries' institutional quality. It can therefore be assumed that the moderating effect of bank market power on the decrease in bank loans during the crisis period is independent of how the type of bank or institutional infrastructure affects the likely creation of lending relationships and, thus, of how lending relationships affect the level of bank market power.

\section{INSERT TABLE 9 ABOUT HERE}

\section{CONCLUDING REMARKS}

Research traditionally associates the negative real effect of banking crises with a reduction in credit supply due to shocks affecting banks' balance sheets (lending channel). Using a sample of 2,806 observations of 735 banks from 17 countries during the 2003-2012 period, we analyze how the recent global financial crisis affected the growth of bank credit. We apply a two-step standard panel data approach to distinguish the direct impact of the crisis on bank lending from the effect that takes place through the changes in market power that occurred in banks during this crisis episode. 
Restructuring of banking sectors during crisis periods may increase the market power of the surviving banks that would take advantage of a privileged position with respect to new potential borrowers coming from insolvent entities. Since borrowers need to find a new lender quickly, banks can afford to require higher interest rates in loan operations. Therefore, in spite of the high information asymmetries, surviving entities would have incentives to lend to non-relationship borrowers. On the other hand, the link between bank market power and credit supply may be associated with ease of access for banks to alternative funding sources. Banks with high market power should have easy access to alternative sources of funding and thus, a greater ability to hedge against loans losses. They therefore have no reasons to cut back their lending.

In this paper, we provide evidence that the reduction in bank loans as a consequence of the recent crisis was not homogeneous across banks, but was counteracted by an indirect effect through the increased level of bank market power also experienced during the crisis years. Moreover, we control for bank regulation and supervision to check that the role of bank market power to shape the impact of the GFC on growth in loans is particularly relevant in countries with less stringent restrictions on non-traditional bank activities and countries with a lower level of supervisory power exercised by official authorities.

It is necessary to mention that the reduction in credit supply that took place, on average, during the GFC is reflecting the needing for diminishing the bank balance sheets, previously inflated and affected by the particular risk-management policies of the pre-crisis years. Therefore, the observed reduction in banks' credit supply may have been due to the deleverage process and adjustment of overcapacity on the path toward a more stable and sustainable financial sector. The results of this research work may have, however, important policy implications. First, our findings recognize the necessary reduction in the size of bank balance sheets after the onset of the GFC. Second, we obtain results suggesting that optimal antitrust legislation should take into account the relevance of changes in market power for mitigating the impact of banking crises on banks' credit supply and, therefore, on economic performance. The study also sheds light on the type of countries where, depending on the stringency of their bank regulation and supervision, policy interventions fostering increases in market power should be adopted during periods of crisis. 
Appendix A. Adjusted Lerner index (Koetter et al. 2012)

We use stochastic frontier analysis (SFA) to estimate marginal cost and average revenues. Firstly, we specify a production technology with three inputs (labor $\left[w_{1}\right]$, fixed assets $\left[w_{2}\right]$, and borrowed funds $\left.\left[w_{3}\right]\right)$ and two outputs (loans and securities). The prices of the three inputs are calculated as follows:

$\mathbf{W}_{1}=$ personnel expense/total assets;

$\mathrm{w}_{2}=$ (total operating expense-personnel expense)/fixed assets;

$W_{3}=$ interest expense/total deposits

Following Koetter et al. (2012) we also include total equity because it can be used to fund loans and reflect different risk attitudes of banks. We assume that factor markets are complete and the bank chooses factor quantities at given factor prices in order to supply a desired output.

To estimate marginal costs, we use a translog total cost function of bank $j$ at time $t$ as:

$$
\begin{aligned}
\operatorname{logTOC}_{j t}=\alpha & +\sum_{i=1}^{3} \beta_{i} \log w_{i j t}+\sum_{p=1}^{2} \gamma_{p} \log y_{p j t}+\delta \log \left(z_{j t}\right)+\sum_{i=1}^{3}(c / 2)\left(\log w_{i j t}\right)^{2} \\
& \left.+\sum_{i<k} \sum_{i k} \varphi_{i o g} w_{i j t} \log w_{k j t}+\sum_{p=1}^{2}(\theta / 2)\left(\log y_{p j t}\right)^{2}+\left(k_{12} / 2\right) \log y_{1 j t} \log y_{2 j t}\right) \\
& +\sum_{i=1}^{3} \sum_{p=1}^{2} \log w_{i j t} \log y_{p j t}+\sum_{k=1}^{2} v_{k} \operatorname{trend}^{k}+\sum_{i=1}^{3} \vartheta \log w_{i j t} \text { trend } \\
& +\sum_{p=1}^{2} \omega \log y_{p j t} \text { trend }+\varepsilon_{j t}
\end{aligned}
$$

where TOC denotes total operating costs, $w_{i j t}$ input factors $i=1,2,3$ of bank $j$ at time $t, y_{1 j t}$ is total loans of bank $j$ in year $t, y_{2 j t}$ is total securities of bank $j$ at time $t, z_{j t}$ is total equity of bank $j$ at time $t$, and trend is a time trend to capture technical change. We impose homogeneity of degree one on input prices by dividing all factor prices and TOC by $w_{3}$. We estimate this equation using a SFA approach. Given the output level of the bank, cost (in)efficiency measures the difference between minimum and observed costs. We assume that $\varepsilon_{j}=v_{j}+u_{i}$, where random error $v_{j}$ is assumed to be iid 
normally distributed with mean zero and variance $\sigma_{v}{ }^{2}$. The $u_{j}$ terms denote systematic deviations from optimal cost due to inefficiency and are assumed to be iid with a half-normal distribution and variance $\sigma_{u}{ }^{2}$ independent of the $v_{j}^{\prime} s$.

Marginal costs are calculated from the sum of the derivatives with respect to total loans $\left(\mathrm{y}_{\mathrm{lj}}\right)$ and total securities $\left(\mathrm{y}_{2 \mathrm{jt}}\right)$, which yields:

$$
\begin{aligned}
M C_{j t}=\frac{T O C_{j t}}{y_{1 j t}}\left[\gamma_{1}+\theta_{1} \log y_{1 j t}+\left(k_{12} / 2\right) \log y_{2 j t}+\sum_{i=1}^{3} \sigma_{1 t} \log w_{i j t}+\omega_{1} \text { trend }\right] \\
+\frac{T O C_{j t}}{y_{2 j t}}\left[\gamma_{2}+\theta_{2} \log _{1 j t}+\left(k_{12} / 2\right) \log y_{1 j t}+\sum_{i=1}^{3} \sigma_{2 t} \log w_{i j t}+\omega_{2} \text { trend }\right]
\end{aligned}
$$

Cross-country comparison of cost efficiency requires estimation of a common cost efficiency frontier for all banks in the sample used. However, when analyzing bank efficiency, it is important to allow for variation in environmental conditions which are beyond the control of bank managers (DeYoung, 1998; Dietsch and Lozano-Vivas, 2000; Lozano-Vivas et al., 2002; Maudos and Fernández de Guevara, 2007). With this aim, we introduce into the cost function dummy variables for each country to take into account the influence of other potential variables which are specific to each banking sector.

To approximate average revenues (or price $\mathrm{p}$ ) in the Lerner index, we take into account potential profit inefficiencies. To measure this efficiency, we use profits before taxes (PBT) as the dependent variable in the translog equation (AI). Using predicted total operating cost (TOC), corresponding marginal costs $(M C)$, and predicted profits $(P B T)$ relative to total output $(T O=$ total loans + total securities), an efficiency-adjusted Lerner index is:

$$
\text { LERNER }=\frac{\frac{P B T}{T O}+\frac{T O C}{T O}-M C}{\frac{P B T}{T O}+\frac{T O C}{T O}}=\frac{P B T+T O C-M C * T O}{P B T+T O C}
$$




\section{Appendix B. Recession variable}

The recession variable is a dummy variable indicating whether a country is experiencing a recession in a particular period. It takes value I for the years identified as economic recession years and 0 otherwise. Recession periods are identified following the Braun and Larrain (2005) methodology. The identification of recession periods follows a peak-to-trough criterion. A trough occurs when current GDP is more than one standard deviation below its trend level (or alternatively, when cyclical GDP is more than one standard deviation below zero), computed using the HodrickPrescott filter with smoothing parameter of 100 . We use the standard deviation of the cyclical GDP of each country. Once the trough is identified, a local peak will be defined as a year where cyclical GDP is higher than the previous and subsequent years. The recession variable takes a value of I for all the years between peak and trough (excluding the peak year), and 0 otherwise. The cyclical component of GDP is constructed with data from 2003 to 2012, when available. The recession dummy is assigned a missing value whenever there are no GDP data or if a trend cannot be reliably constructed.

\section{REFERENCES}

Adams, R., Amel, D., (2005). "The Effects of Local Banking Market Structure on the Bank Lending Channel of Monetary Policy”. Working Paper No. 2005-16. Board of Governors of the Federal Reserve System.

Altunbas, Y., Fazylov, O., Molyneux, P., (2002). "Evidence on the bank lending channel in Europe”. Journal of Banking and Finance, 26 (I I): 2093-2I I0.

Altunbas, Y., Gambacorta, L., Marques-lbanez, D., (2009). "Securitisation and the bank lending channel”. European Economic Review, 53 (8): 996-1009.

Altunbas, Y., Gambacorta, L., Marques-Ibanez, D., (2010). "Bank risk and monetary policy”. Journal of Financial Stability, 6 (3): $121-129$.

Barth, J. R., Caprio, G. Jr., Levine, R., (20I3). "Bank regulation and supervision in 180 countries from 1999 to 20II." NBER Working Paper No. 18733. 
Barth, J.R, Caprio G. Jr, Levine R., (2006). "Rethinking bank regulation: till angels govern”. Cambridge University Press.

Barth, J.R, Caprio G. JR, Levine R., (2008). "Bank regulations are changing: for better or worse?" Comparative Economic Studies 50 (4): 537-563.

Beck, T., De Jonghe, O., Schepens, G., (2013). "Bank competition and stability: cross country heterogeneity”. Journal of Financial Intermediation, 22: 218-244.

Beck, T., Demirgüç-Kunt, A., Maksimovic, V., (2006). "The influence of financial and legal institutions on firm size”. Journal of Banking and Finance, 30: 2995-30I5.

Berger, A.N., (1995). "The profit-structure relationship in banking: tests of market power and efficient structure hypotheses”. Journal of Money, Credit and Banking, 27: 404-43I.

Berlin, M., Mester, L.J., (1999). “Deposits and relationship lending”. Review of Financial Studies, I2: 579-607.

Bharath, S., Dahiya, S., Saunders, A., Srinivasan, A., (2007): "So what do I get? The bank's view of lending relationships”. Journal of Financial Economics 85: 368-419.

Boot, A. W. A. (2000). Relationship banking: What do we know? Journal of Financial Intermediation, 9: 7-25.

Braun, M., Larrain, B., (2005). "Finance and the Business Cycle: International, Inter-Industry Evidence”. Journal of Finance, 15 (3): 1097-128.

Brissimis, S., Delis, M., (2010). "Bank heterogeneity and monetary policy transmission”. ECB Working Paper No. 1233.

Brissimis, S., Delis, M., losifidi, M., (20I2). Bank market power and monetary policy transmission”. MPRA Paper No. 49206. University Library of Munich.

Campbell, T. Kracaw, W., (1980). Information production, market signaling, and the theory of intermediation. Journal of Finance, 35: 863-882. 
Cetorelli, N., Gambera, M., (200I). "Banking market structure, financial dependence and growth: international evidence from industry data”. Journal of Finance, 56: 617-648.

Chaffai, M., Dietsch, M., Lozano-Vivas, A., (200I). "Technological and environmental differences in the European banking industries”. Journal of Financial Services Research, 19 (2/3):147-162.

Chava, S., Purnanandam, A., (20II). "The effects of banking crises on bank-dependent borrowers". Journal of Financial Economics, 99: 755-786.

Cubillas, E, González, F., (20|4). "Financial liberalization and bank risk-taking: international evidence”. Journal of Financial Stability, II: 32-48.

Cubillas, E., Suárez, N., (20I3). "Bank market power after a banking crisis: some international evidence”. The Spanish Review of Financial Economics, I I: 13-28.

D’Auria, C., Foglia, A., Reedtz, P., (1999). "Bank interest rates and credit relationship in Italy”. Journal of Banking and Finance, 23, 1067-1093.

De Haan, L., Van den End, J. W., (20I3). “Banks' response to funding liquidity shocks: lending adjustment, liquidity hoarding and fire sales”. Journal of International Financial Markets, Institutions \& Money, 26: I52-174.

Degryse, H., Ongena, S., (2005). “Distance, lending relationships, and competition”. Journal of Finance, 60: 231-266.

Dell'Ariccia, G., Detragiache, E., Rajan. R., (2008). “The real effects of banking crises”. Journal of Financial Intermediation, 7: 89-II2.

Dell'Ariccia, G., Marquez, R. (2004). Information and bank credit allocation. Journal of Financial Economics, 72: 185-214.

Detragiache, E., Garella, P., Guiso, L., (2000). "Multiple versus single banking relationships: theory and evidence". Journal of Finance, 55: II33-1 I6I. 
DeYoung, R., (1998). “X-inefficiency and management quality in commercial banks". Journal of Financial Services Research, 13: 5-22.

Diamond, D., (199I). “Financial intermediation and delegated monitoring”. Review of economic Studies, 5I: 393-4I4.

Dietsch, M., Lozano-Vivas, A., (2000). "How the environment determines the efficiency of banks: A comparison between French and Spanish banking industry”. Journal of Banking and Finance, 24: 985-1004.

Ehrmann, M., Gambacorta, L., Martinez, J., Sevestre, P., Worms, A., (2003). "Financial systems and the role of banks in monetary policy transmission in the Euro Area". Cambridge University Press, Cambridge.

Elyasiani, E., Goldberg, L.G., (2004): "Relationship lending: a survey of the literature”. Journal of Economics and Business 56: 315-330.

Fama, E., (1985). “What's different about banks?”. Journal of Monetary Economics, I5: 29-36.

Fernández, A.I., González, F., Suárez, N., (2010). "How institutions and regulation shape the influence of bank concentration on economic growth: International evidence”. International Review of Law and Economics, 30: 28-36.

Fernández, A.I., González, F., Suárez, N., (20/3a). "How do bank competition, regulation, and institutions shape the real effect of banking crises? International evidence". Journal of International Money and Finance, 33: 19-40.

Fernández, A.I., González, F., Suárez, N., (20/3b). "The real effects of banking crises: finance or asset allocation effects? Some international evidence". Journal of Banking and Finance, 37: 24I9-2433.

Fernández, A.I., González, F., Suárez, N., (2018). "Bank supply shocks and the substitution between bank and nonbank debt”. Journal of Corporate Finance, 48: 122- I47. 
Fratzscher, M., König, P.J., Lambert, C., (2016). "Credit provision and banking stability after the Great Financial Crisis: The role of bank regulation and the quality of governance". Journal of International Money and Finance, 66: II3-135.

Fungáçová, Z., Solanko, L., Weill, L., (20|4). “Does competition influence the bank lending channel in the Euro Area?" Journal of Banking and Finance, 49: 356-366.

Gambacorta, L., (2005). “Inside the bank lending channel”. European Economic Review, 49: I7371759.

Gambacorta, L., Marques-lbanez, D., (20II). "The bank lending channel: lessons from the crisis". Economic Policy, 26 (66): I35-I82.

Gatev, E., Strahan P.E., Schuermann, T., (2004). “How do banks manage liquidity risk: evidence from equity and deposit markets in the Fall of 1998”. NBER Working Paper No. 1982.

Gorton, G., Winton, A., (2003). “Financial Intermediation”. In George Constantinides, Milton Harris, and Ren Stulz (eds.), Handbooks in the Economics of Finance, Volume IA: Corporate Finance, Elsevier Science, Amsterdam.

Gujarati, D., (2003). “Basic Econometrics”. New York: McGraw-Hill.

Hadad, M.D., Agusman, A., Monroe, G.S., Gasbarro, D., Zumwalt, J.K., (20II). "Market discipline, financial crisis and regulatory changes: evidence from Indonesian banks". Journal of Banking and Finance, 35: 1552-1562.

Haubrich, J., (1989). "Financial intermediation, delegated monitoring and long-term relationships". Journal of Banking and Finance, 13: 9-20.

Hellmann, T.F., Murdock, K.C., Stiglitz, J.E., (2000). "Liberalization, moral hazard in banking, and prudential regulation: are capital requirements enough?" American Economic Review, 90 (I): |47-165. 
Jimenez, G., Ongena, S., Peydro, J., Saurina, J., (2012). "Credit supply and monetary policy: identifying the bank balance-sheet channel with loan applications". American Economic Review, 102: 230I-2326.

Kashyap, A., Stein, J., (1995). "The impact of monetary policy on bank balance sheets". CarnegieRochester Conference Series on Public Policy, June: I5I-195.

Kashyap, A., Stein, J., (2000). "What do a million observations in banks say about the transmission of monetary policy?" American Economic Review, 90: 407-428.

Keeley, M.C., (1990). "Deposit insurance, risk, and market power”. American Economic Review, 80: $1183-1200$.

Khwaja, A., Mian, A., (2008). "Tracing the impact of bank liquidity shocks: evidence from an emerging market”. American Economic Review, 98: 1413-1442.

Kim, D., Sohn, W., (2017). “The effect of bank capital on lending: Does liquidity matter?" Journal of Banking and Finance, 77: 95-107.

Kishan, R., Opiela, T., (2000). "Bank size, bank capital, and the bank lending channel”. Journal of Money, Credit and Banking, 32: |2|-|4|.

Klein, M.A., (197I). "A theory of the banking firm". Journal of Money, Credit and Banking, 3(2): 205-218.

Koetter, M., Kolari, J., Spierdijk, L., (2012). "Enjoying the quiet life under deregulation? Evidence from adjusted Lerner indices for U.S. banks". The Review of Economics and Statistics 94: $462-480$.

Kroszner, R.S., Laeven, L. Klingebiel, D., (2007). "Banking crises, financial dependence and growth”. Journal of Financial Economics, 84: 187-228.

La Porta, R., Lopez-de-Silanes, F., Shleifer, A. (1997). Legal determinants of external finance. The Journal of Finance, 52: ||3|-| | 50 . 
La Porta, R., Lopez-de-Silanes, F., Shleifer, A. (1998). Law and finance. Journal of Political Economy, 106: III3-1155.

Laeven, L., Levine, R., (2009). "Bank governance, regulation and risk taking”. Journal of Financial Economics, 93: 259-275.

Laeven, L., Valencia, F., (2008). "Systemic banking crises: a new database”. IMF Working Paper, WP/08/224.

Laeven, L., Valencia, F., (20I2). "Systemic banking crises database: an update”. IMF Working Paper, WP/I2/I63.

Leland, H., Pyle, D., (1977). "Information asymmetries, financial structure, and financial intermediaries”. Journal of Finance, 32: 37I-387.

Leroy, A., (2014). “Competition and the bank lending channel in Eurozone”. Journal of International Financial Markets, Institutions \& Money, 3 I: 296-3 I4.

Loutskina, E., Strahan, P.E., (2009). "Securitization and the declining impact of bank finance on loan supply: evidence from mortgage originations”. Journal of Finance, 64 (2): 86I-889.

Love I., Lorenzo A. P., Sarria-Allende, V., (2007). "Trade credit and bank credit: evidence from recent financial crises”. Journal of Financial Economics, 83: 453-469.

Lozano-Vivas, A., Pastor, J., Pastor, J.M., (2002). “An efficiency comparison of European banking systems operating under different environmental conditions". Journal of Productivity Analysis, 18: 59-77.

Maudos, J., Fernández De Guevara, J., (2004). "Factors explaining the interest margin in the banking sectors of the European Union”. Journal of Banking and Finance, 28: 2259-228I.

Maudos, J., Fernández De Guevara, J., (2007). “The Cost of Market Power in Banking: Social Welfare Loss Vs. Cost Inefficiency,” Journal of Banking and Finance, 3 I: 2103-2I 35. 
Olivero, M.P., Li, Y., Jeon, B.N., (20Ila). "Consolidation in banking and the lending channel of monetary transmission”. Journal of International Money and Finance, 30: 1034-1054.

Olivero, M.P., Li, Y., Jeon, B.N., (20l lb). "Competition in banking and the lending channel: evidence from bank-level data in Asia and Latin America”. Journal of Banking and Finance, 35: 560571.

Petersen, M. A., Rajan, R. G., (1994). "The benefits of lending relationships: evidence from small business data”. Journal of Finance, 49: 1367-1400.

Petersen, M. A., Rajan, R. G., (1995). "The effect of credit market competition on lending relationships". Quarterly Journal of Economics, I10: 407-443.

Repullo, R., (2004). “Capital requirements, market power, and risk-taking in banking”. Journal of Financial Intermediation, 13: 156-182.

Schliephake, E., (2016). "Capital regulation and competition as a moderator for banking stability". Journal of Money, Credit and Banking, 48 (8): I787-I8|4.

Sharpe, S.,(1995). "Bank Capitalization, Regulation, and the Credit Crunch: A Critical Review of the Research Findings." Finance and Economics Discussion Series Paper No. 95/20, Board of Governors of the Federal Reserve System.

Thakor, A. (2018). Post-crisis regulatory reform in banking: Address insolvency risk, not illiquidity! Journal of Financial Stability (in press).

Van den Heuvel, S., (2002). “Does bank capital matter for monetary transmission?” Economic Policy Review, Federal Reserve Bank of New York, 259-265.

Wheelock D.C., (20II). "Banking industry consolidation and market structure: Impact of the financial crisis and recession”. Federal Reserve Bank of St. Louis Review, 93(6): 4I9-38. 
Table I: GFC inception dates, banks, and observations per country

This table shows the inception dates of the Global Financial Crisis (GFC) in each country following the Laeven and Valencia (2012) database. The table also reports the number of banks and observations per country included in the analysis. Our final sample consists of 735 banks from 17 countries.

\begin{tabular}{lccc}
\hline \hline COUNTRY & Crisis year & \#Banks & \#Observations \\
\hline Austria & 2008 & 38 & 136 \\
Belgium & 2008 & 16 & 48 \\
Denmark & 2008 & 37 & 165 \\
Germany & 2008 & 78 & 250 \\
Greece & 2008 & 13 & 43 \\
Iceland & 2008 & 4 & 8 \\
Ireland & 2008 & 9 & 26 \\
Italy & 2008 & 64 & 286 \\
Latvia & 2008 & 19 & 62 \\
Luxembourg & 2008 & 49 & 170 \\
Mongolia & 2008 & 2 & 5 \\
Netherlands & 2008 & 19 & 74 \\
Nigeria & 2009 & 15 & 55 \\
Spain & 2008 & 31 & 79 \\
Ukraine & 2009 & 39 & 141 \\
United Kingdom & 2007 & 57 & 160 \\
United States & 2007 & 245 & 1,098 \\
\hline \hline TOTAL & & 735 & 2,806 \\
\hline \hline
\end{tabular}




\section{Table 2: Descriptive statistics and correlations}

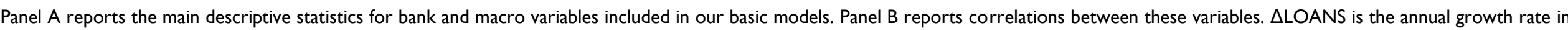

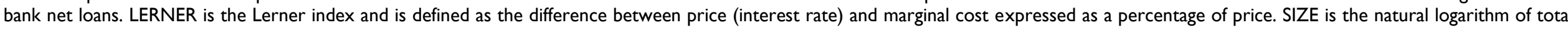

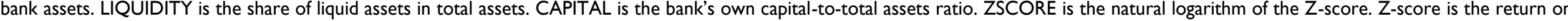

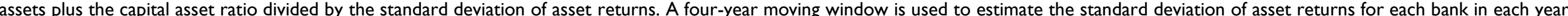

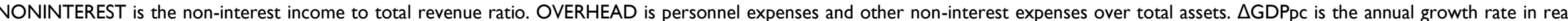
GDP per capita. FINFREE is the index of financial liberalization of each country.

\begin{tabular}{|c|c|c|c|c|c|c|c|c|c|c|}
\hline \multicolumn{11}{|c|}{ PANEL A } \\
\hline & $\triangle$ LOANS & LERNER & SIZE & LIQUIDITY & CAPITAL & ZSCORE & NONINTEREST & OVERHEAD & $\Delta \mathrm{GDPpc}$ & FINFREE \\
\hline Mean & 0.0038 & 0.1538 & 14.7209 & 0.2354 & 0.3543 & 1.3181 & 0.2233 & 0.0313 & 2.4694 & 74.6400 \\
\hline Std. Dev. & 0.0247 & 0.3421 & 1.8032 & 0.2240 & 0.5027 & 0.4220 & 0.2127 & 0.0283 & 3.2252 & 16.3057 \\
\hline Median & 0.0002 & 0.2047 & 14.6042 & 0.1569 & 0.1277 & 1.3377 & 0.1894 & 0.0267 & 1.9099 & 80 \\
\hline Minimum & -0.0570 & 0 & 10.1596 & 0.0087 & 0.0103 & -1.2029 & -0.6032 & 0.0013 & -5.6007 & 30 \\
\hline Maximum & 0.8992 & 0.9145 & 19.7815 & 0.9256 & 3.5901 & 2.8990 & 0.9346 & 0.4732 & 30.3422 & 90 \\
\hline VIF & & 5.96 & 15.15 & 2.94 & 3.86 & 9.15 & 3.83 & 3.07 & 1.90 & 9.51 \\
\hline \multicolumn{11}{|c|}{ PANEL B } \\
\hline & $\triangle$ LOANS & LERNER & SIZE & LIQUIDITY & CAPITAL & ZSCORE & NONINTEREST & OVERHEAD & $\Delta \mathrm{GDPpc}$ & FINFREE \\
\hline LERNER & $-0.0532 * * *$ & & & & & & & & & \\
\hline SIZE & $-0.234 I^{* * *}$ & $0.043 I^{* *}$ & & & & & & & & \\
\hline LIQUIDITY & $0.0530 * * *$ & $-0.1260 * * *$ & $-0.1155^{* * *}$ & & & & & & & \\
\hline CAPITAL & 0.0131 & $-0.0396 * *$ & -0.0062 & -0.0310 & & & & & & \\
\hline ZSCORE & $-0.0621^{* * * *}$ & $0.1388 * * *$ & $0.0397 * *$ & $-0.2287 * * *$ & $0.0542 * * *$ & & & & & \\
\hline NONINTEREST & $0.0923 * * *$ & -0.0032 & $-0.1003 * * *$ & $0.3786 * * *$ & $-0.2393 * * *$ & $-0.1880 * * *$ & & & & \\
\hline OVERHEAD & $0.1778 * * *$ & $-0.0744 * * *$ & $-0.2169 * * *$ & $-0.0639 * * *$ & -0.0070 & $-0.1991 * * *$ & $0.4350 * * *$ & & & \\
\hline$\Delta \mathrm{GDPpc}$ & $0.1024 * * *$ & 0.0265 & $-0.1783 * * *$ & $0.2042^{* * *}$ & $-0.2694 * * *$ & $-0.1621^{* * *}$ & $0.1108 * * *$ & $0.1302 * * *$ & & \\
\hline FINFREE & $0.0785 * * *$ & $0.3354 * * *$ & $0.0785^{* * *}$ & $-0.2003^{* * * *}$ & $-0.1038 * * *$ & $0.1395 * * *$ & $-0.0444 * *$ & $-0.1206 * * *$ & $-0.2823 * * *$ & I \\
\hline
\end{tabular}


This table presents results examining the effect of the GFC on the Lerner index of each bank from each country. The table also reports the results testing if bank-level characteristics shape the influence of the GFC on the Lerner index. In column (I) results of a random effects estimation are shown. According to the results of the Hausman test, in columns (2) to (8) fixed effects estimations are presented. The dependent variable (LERNER) is the Lerner index. It is defined as the difference between price (interest rate) and marginal cost expressed as a percentage of price. GFC is a dummy variable identifying the crisis period in each country. SIZE is the natural logarithm of total bank assets. LIQUIDITY is the share of liquid assets in total assets. OVERHEAD is personnel expenses and other non-interest expenses over total assets. ZSCORE is the natural logarithm of the Z-score. Z-score is the return on assets plus the capital asset ratio divided by the standard deviation of asset returns. A four-year moving window is used to estimate the standard deviation of asset returns for each bank in each year. NONINTEREST is the non-interest income to total revenue ratio. CAPITAL is the bank's own capital-to-total assets ratio. $\triangle G D P p c$ is the annual growth rate in real GDP per capita. RECESSION is a dummy variable that takes value I if it is a year classified as a recession year following the Braun and Larrain (2005) methodology. FINFREE is the index of financial liberalization. $* * * ; *$ and $*$ indicate statistical significance at I, 5 , and 10 percent, respectively.

\begin{tabular}{|c|c|c|c|c|c|c|c|c|}
\hline $\begin{array}{l}\text { Dependent variable: } \\
\text { LERNER INDEX }\end{array}$ & (I) & (2) & (3) & (4) & (5) & (6) & (7) & (8) \\
\hline GFC & $\begin{array}{l}0.2046 * * * \\
(2.69)\end{array}$ & $\begin{array}{l}0.2168^{* * * *} \\
(2.81)\end{array}$ & $\begin{array}{l}0.2212 * * * \\
(2.67)\end{array}$ & $\begin{array}{l}0.1258 \\
(1.62)\end{array}$ & $\begin{array}{l}0.2195^{* * * *} \\
(2.84)\end{array}$ & $\begin{array}{l}0.175 I^{* *} \\
(2.24)\end{array}$ & $\begin{array}{l}0.2047 * * * \\
(2.65)\end{array}$ & $\begin{array}{l}0.2170 * * * \\
(2.82)\end{array}$ \\
\hline FINFREE & $\begin{array}{c}-0.0006 * * \\
(-2.05)\end{array}$ & $\begin{array}{l}-0.0006 * * \\
(-1.97)\end{array}$ & $\begin{array}{c}-0.0006 * \\
(-1.96)\end{array}$ & $\begin{array}{c}-0.0010 * * * \\
(-3.35)\end{array}$ & $\begin{array}{c}-0.0005^{*} \\
(-1.93)\end{array}$ & $\begin{array}{l}-0.0005^{*} \\
(-1.79)\end{array}$ & $\begin{array}{c}-0.0006 * * \\
(-2.26)\end{array}$ & $\begin{array}{c}-0.0006 * * \\
(-1.97)\end{array}$ \\
\hline GFC * SIZE & & & $\begin{array}{c}-0.0002 \\
(-0.14)\end{array}$ & & & & & \\
\hline GFC * LIQUIDITY & & & & $\begin{array}{l}0.1570 * * * \\
(6.07)\end{array}$ & & & & \\
\hline GFC * CAPITAL & & & & & $\begin{array}{c}-0.0112 \\
(-0.52)\end{array}$ & & & \\
\hline GFC * Z-SCORE & & & & & & $\begin{array}{l}0.0304 * * * \\
(3.12)\end{array}$ & & \\
\hline GFC * NONINTEREST & & & & & & & $\begin{array}{l}0.0442^{* *} \\
(2.21)\end{array}$ & \\
\hline GFC * OVERHEAD & & & & & & & & $\begin{array}{l}-0.0171 \\
(-0.10)\end{array}$ \\
\hline SIZE & $\begin{array}{l}0.0054 * * * \\
(2.91)\end{array}$ & $\begin{array}{l}0.005 I \\
(0.89)\end{array}$ & $\begin{array}{l}0.0052 \\
(0.90)\end{array}$ & $\begin{array}{l}0.0049 \\
(0.87)\end{array}$ & $\begin{array}{l}0.0054 \\
(0.94)\end{array}$ & $\begin{array}{l}0.0049 \\
(0.87)\end{array}$ & $\begin{array}{l}0.0055 \\
(0.96)\end{array}$ & $\begin{array}{l}0.0050 \\
(0.88)\end{array}$ \\
\hline LIQUIDITY & $\begin{array}{c}-0.0358 * * \\
(-2.53)\end{array}$ & $\begin{array}{c}-0.0640^{* * * *} \\
(-3.20)\end{array}$ & $\begin{array}{c}-0.064 I^{* * * *} \\
(-3.20)\end{array}$ & $\begin{array}{c}-0.0942^{* * * *} \\
(-4.60)\end{array}$ & $\begin{array}{c}-0.0668^{* * * *} \\
(-3.22)\end{array}$ & $\begin{array}{c}-0.0618 * * * \\
(-3.09)\end{array}$ & $\begin{array}{c}-0.0615^{* * *} \\
(-3.07)\end{array}$ & $\begin{array}{c}-0.0640 * * * \\
(-3.19)\end{array}$ \\
\hline CAPITAL & $\begin{array}{c}0.0042 \\
(0.85)\end{array}$ & $\begin{array}{c}-0.0080 \\
(-1.49)\end{array}$ & $\begin{array}{c}-0.0081 \\
(-1.50)\end{array}$ & $\begin{array}{c}-0.0041 \\
(-0.77)\end{array}$ & $\begin{array}{l}0.0026 \\
(0.13)\end{array}$ & $\begin{array}{c}-0.0094 * \\
(-1.75)\end{array}$ & $\begin{array}{l}-0.0063 \\
(-1.18)\end{array}$ & $\begin{array}{c}-0.0080 \\
(-1.50)\end{array}$ \\
\hline Z-SCORE & $\begin{array}{l}0.0198^{* * * *} \\
(3.88)\end{array}$ & $\begin{array}{c}0.0354 * * * \\
(5.58)\end{array}$ & $\begin{array}{c}0.0354 * * * \\
(5.58)\end{array}$ & $\begin{array}{l}0.0325 * * * \\
(5.16)\end{array}$ & $\begin{array}{c}0.0350 * * * \\
(5.49)\end{array}$ & $\begin{array}{c}0.0225 * * * \\
(2.99)\end{array}$ & $\begin{array}{c}0.0340 * * * \\
(5.33)\end{array}$ & $\begin{array}{c}0.0354 * * * \\
(5.58)\end{array}$ \\
\hline NONINTEREST & $\begin{array}{c}0.0817^{* * * *} \\
(6.21)\end{array}$ & $\begin{array}{c}0.0535 * * * \\
(3.28)\end{array}$ & $\begin{array}{c}0.0532 * * * \\
(3.22)\end{array}$ & $\begin{array}{c}0.0365 * * \\
(2.22) \\
0.5409 * * *\end{array}$ & $\begin{array}{c}0.0540 * * * \\
(3.30)\end{array}$ & $\begin{array}{c}0.0445 * * * \\
(2.69)\end{array}$ & $\begin{array}{c}0.0212 \\
(0.97)\end{array}$ & $\begin{array}{c}0.0537 * * * \\
(3.26)\end{array}$ \\
\hline OVERHEAD & $\begin{array}{c}-0.5669 * * * \\
(-5.64)\end{array}$ & $\begin{array}{c}-0.6197 * * * \\
(-4.34)\end{array}$ & $\begin{array}{c}-0.6186 * * * \\
(-4.33)\end{array}$ & $\begin{array}{c}-0.5409 * * * \\
(-3.8 \mathrm{I})\end{array}$ & $\begin{array}{c}-0.6306 * * * \\
(-4.37)\end{array}$ & $\begin{array}{c}-0.6408 * * * \\
(-4.49)\end{array}$ & $\begin{array}{c}-0.5498 * * * \\
(-3.57)\end{array}$ & $\begin{array}{c}-0.6220 * * * \\
(-4.30)\end{array}$ \\
\hline$\triangle G D P p c$ & $\begin{array}{c}0.0001 \\
(0.20)\end{array}$ & $\begin{array}{c}0.0003 \\
(0.47)\end{array}$ & $\begin{array}{l}0.0003 \\
(0.47)\end{array}$ & $\begin{array}{c}0.0002 \\
(0.38)\end{array}$ & $\begin{array}{c}0.0003 \\
(0.53)\end{array}$ & $\begin{array}{c}0.0002 \\
(0.38)\end{array}$ & $\begin{array}{l}0.0002 \\
(0.37)\end{array}$ & $\begin{array}{c}0.0003 \\
(0.47)\end{array}$ \\
\hline RECESSION & $\begin{array}{c}0.0135^{* * *} \\
(2.24)\end{array}$ & $\begin{array}{c}0.0144^{* *} \\
(2.37)\end{array}$ & $\begin{array}{c}0.0144 * * \\
(2.37)\end{array}$ & $\begin{array}{c}0.0181 * * * * \\
(2.98)\end{array}$ & $\begin{array}{c}0.0143^{* * *} \\
(2.34)\end{array}$ & $\begin{array}{c}0.0141 * * \\
(2.33)\end{array}$ & $\begin{array}{c}0.0150 * * \\
(2.46)\end{array}$ & $\begin{array}{c}0.0144 * * \\
(2.37)\end{array}$ \\
\hline Country dummies & YES & $\mathrm{NO}$ & $\mathrm{NO}$ & $\mathrm{NO}$ & $\mathrm{NO}$ & $\mathrm{NO}$ & $\mathrm{NO}$ & $\mathrm{NO}$ \\
\hline Year dummies & YES & YES & YES & YES & YES & YES & YES & YES \\
\hline Hausman Test & - & $65.24 * * *$ & $69.24 * * *$ & $73.20 * * *$ & $57.29 * * *$ & $65.33^{* * * *}$ & $74.96 * * *$ & $66.69 * * *$ \\
\hline Wald Test & $\mathrm{I}, 187.83^{* * * *}$ & - & - & - & - & - & - & - \\
\hline $\mathrm{F}-$ Test & - & $52.56 * * *$ & $49.62 * * *$ & $52.56 * * *$ & $49.64 * * *$ & $50.39 * * *$ & $50.01 * * *$ & $49.62 * * *$ \\
\hline $\mathrm{R}^{2}$ & 0.3028 & 0.3032 & 0.3032 & 0.3154 & 0.3033 & 0.3064 & 0.3048 & 0.3032 \\
\hline \# Observations & 2,806 & 2,806 & 2,806 & 2,806 & 2,806 & 2,806 & 2,806 & 2,806 \\
\hline \# Banks & 735 & 735 & 735 & 735 & 735 & 735 & 735 & 735 \\
\hline \# Countries & 17 & 17 & 17 & 17 & 17 & 17 & 17 & 17 \\
\hline
\end{tabular}


This table presents results examining if bank regulation and supervision shape the effect of the GFC on the Lerner index. The dependent variable (LERNER) is the Lerner index. It is defined as the difference between price (interest rate) and marginal cost expressed as a percentage of price. GFC is a dummy variable identifying the crisis period in each country. RESTRICTI is an index identifying the extent to which all types of non-traditional banking activities (insurance, real estate, securities, and participation on the capital and control of non-financial firms) are prohibited, restricted or permitted in each country. RESTRICT2 indicates the legal restrictions for banks on insurance, real estate, and securities activities. OWN refers to the legal restrictions for banks to participate in the ownership and control of non-financial firms. CAPREG is an index referred to the stringency of regulation on bank capital. SUPPOW refers to the supervisory power by official banking authorities. MONITOR is an index referred to the private monitoring executed on banking activities. SIZE is the natural logarithm of total bank assets. LIQUIDITY is the share of liquid assets in total assets. OVERHEAD is personnel expenses and other noninterest expenses over total assets. ZSCORE is the natural logarithm of the Z-score. Z-score is the return on assets plus the capital asset ratio divided by the standard deviation of asset returns. A four-year moving window is used to estimate the standard deviation of asset returns for each bank in each year. NONINTEREST is the non-interest income to total revenue ratio. CAPITAL is the bank's own capital-to-total assets ratio. $\triangle G D P p c$ is the annual growth rate in real GDP per capita. RECESSION is a dummy variable that takes value I if it is a year classified as a recession year following the Braun and Larrain (2005) methodology. FINFREE is the index of financial liberalization. ***; ** and * indicate statistical significance at I, 5 , and I0 percent, respectively.

\begin{tabular}{|c|c|c|c|c|c|c|}
\hline $\begin{array}{l}\text { Dependent variable: } \\
\text { LERNER }\end{array}$ & (I) & (2) & (3) & (4) & (5) & (6) \\
\hline $\begin{array}{l}\text { GFC } \\
\text { FINFREE }\end{array}$ & $\begin{array}{c}0.3595^{* * *} \\
(4.65) \\
-0.0019 * * * \\
(-5.02)\end{array}$ & $\begin{array}{c}0.3175 * * * \\
(4.70) \\
-0.0024 * * * \\
(-6.24)\end{array}$ & $\begin{array}{c}0.2867 * * * \\
(3.80) \\
-0.0022^{* * *} \\
(-6.44)\end{array}$ & $\begin{array}{c}0.2622^{* * * *} \\
(3.44) \\
-0.0018^{* * *} \\
(-5.38)\end{array}$ & $\begin{array}{c}0.2903 \text { *** } \\
(3.03) \\
-0.0007 \text { ** } \\
(-2.08)\end{array}$ & $\begin{array}{c}0.3009 \text { *** } \\
(4.06) \\
-0.0014 * * * \\
(-3.34)\end{array}$ \\
\hline GFC * RESTRICTI & $\begin{array}{c}-0.0256 * * * \\
(-8.59)\end{array}$ & & & & & \\
\hline GFC * RESTRICT2 & & $\begin{array}{c}-0.0287 * * * * \\
(-10.4 I)\end{array}$ & & & & \\
\hline GFC * OWN & & & $\begin{array}{c}-0.0453 * * * \\
(-8.95)\end{array}$ & & & \\
\hline GFC * CAPREG & & & & $\begin{array}{c}-0.0143 * * * \\
(-4.35)\end{array}$ & & \\
\hline GFC * SUPPOW & & & & & $\begin{array}{r}-0.0071 \\
(-1.43)\end{array}$ & \\
\hline GFC * MONITOR & & & & & & $\begin{array}{c}-0.0169 * * * \\
(-4.04)\end{array}$ \\
\hline RESTRICTI & $\begin{array}{c}0.0119 * * * \\
(4.49)\end{array}$ & & & & & \\
\hline RESTRICT2 & & $\begin{array}{l}0.0011 \\
(0.50)\end{array}$ & & & & \\
\hline OWN & & & $\begin{array}{l}0.0020 \\
(0.36)\end{array}$ & & & \\
\hline CAPREG & & & & $\begin{array}{c}-0.0114 * * * * \\
(-7.44)\end{array}$ & & \\
\hline SUPPOW & & & & & $\begin{array}{c}-0.0042 * * * \\
(-3.55)\end{array}$ & \\
\hline MONITOR & & & & & & $\begin{array}{c}0.024 I^{* * *} \\
(7.30)\end{array}$ \\
\hline $\begin{array}{l}\triangle G D P p C \\
\text { RECESSION }\end{array}$ & $\begin{array}{c}-0.0002 \\
(-0.31) \\
0.0233 * * * \\
(3.45) \\
\end{array}$ & $\begin{array}{c}0.0020 * \\
(1.68) \\
0.0286 * * * \\
(3.76) \\
\end{array}$ & $\begin{array}{c}-0.0001 \\
(-0.19) \\
0.0260^{* * * *} \\
(3.94) \\
\end{array}$ & $\begin{array}{c}-0.000 \mathrm{I} \\
(-0.23) \\
0.0157^{* *} \\
(2.4 \mathrm{I}) \\
\end{array}$ & $\begin{array}{l}0.0002 \\
(0.40) \\
0.0092 \\
(1.37) \\
\end{array}$ & $\begin{array}{c}0.0032^{* *} \\
(2.25) \\
0.0107 \\
(1.36) \\
\end{array}$ \\
\hline Bank-level control variables & YES & YES & YES & YES & YES & YES \\
\hline Year dummies & YES & YES & YES & YES & YES & YES \\
\hline F-Test & $53.66 * * *$ & $59.40 * * *$ & $55.52^{* * * *}$ & $58.17 * * *$ & $53.25 * * *$ & $56.04 * * *$ \\
\hline $\mathrm{R}^{2}$ & 0.3427 & 0.3579 & 0.3505 & 0.3607 & 0.3431 & 0.3444 \\
\hline \# Observations & 2,697 & 2,658 & 2,697 & 2,701 & 2,679 & 2,659 \\
\hline \# Banks & 723 & 722 & 723 & 723 & 723 & 721 \\
\hline \# Countries & 16 & 16 & 16 & 16 & 16 & 16 \\
\hline
\end{tabular}




\section{Table 5: GFC and loans growth: the effect of bank market power}

This table presents results examining the direct effect GFC on loans growth and its effect through changes in bank market power. The dependent variable ( $\triangle$ LOANS) is the annual growth rate in net loans by individual banks. GFC is a dummy variable identifying the crisis period in each country. In PANEL A, we present the results of analyzing the direct effect of the global financial crisis on bank credit supply (coefficient of GFC). LERNERp are the predicted values of the Lerner index obtained from the first stage estimations. In PANEL B, we also show the indirect effect through changes in bank market power occurred during the crisis (coefficient of LERNERp*GFC). Columns (I) and (3) report the results of random effects estimations. Columns (2) and (4) report the results of fixed effects estimations. SIZE is the natural logarithm of total bank assets. LIQUIDITY is the share of liquid assets in total assets. OVERHEAD is personnel expenses and other non-interest expenses over total assets. ZSCORE is the natural logarithm of the Z-score. Z-score is the return on assets plus the capital asset ratio divided by the standard deviation of asset returns. A four-year moving window is used to estimate the standard deviation of asset returns for each bank in each year. NONINTEREST is the non-interest income to total revenue ratio. CAPITAL is the bank's own capital-to-total assets ratio. $\triangle G D P p c$ is the annual growth rate in real GDP per capita. RECESSION is a dummy variable that takes value I if it is a year classified as a recession year following the Braun and Larrain (2005) methodology. ***; ** and * indicate statistical significance at I, 5, and 10 percent, respectively.

\begin{tabular}{|c|c|c|c|c|}
\hline \multirow[b]{2}{*}{$\begin{array}{l}\text { Dependent variable: } \\
\text { LOANS GROWTH }\end{array}$} & \multicolumn{2}{|c|}{$\begin{array}{c}\text { PANEL A: } \\
\text { Direct effect of GFC }\end{array}$} & \multicolumn{2}{|c|}{$\begin{array}{c}\text { PANEL B: } \\
\text { Indirect effect through LERNER }\end{array}$} \\
\hline & (I) & (2) & (3) & (4) \\
\hline GFC & $\begin{array}{c}-0.0827^{* *} \\
(-2.02)\end{array}$ & $\begin{array}{c}-0.0834 * \\
(-1.97)\end{array}$ & $\begin{array}{c}-0.1669 * * * \\
(-4.15)\end{array}$ & $\begin{array}{c}-0.1923 * * * \\
(-4.61)\end{array}$ \\
\hline LERNERp & $\begin{array}{l}0.3528 * * \\
(2.32)\end{array}$ & $\begin{array}{c}0.3000 * \\
(1.90)\end{array}$ & $\begin{array}{l}0.2946 * * \\
(2.26)\end{array}$ & $\begin{array}{l}0.2377^{*} \\
(1.75)\end{array}$ \\
\hline LERNERp * GFC & & & $\begin{array}{l}0.2380 * * * \\
(6.06)\end{array}$ & $\begin{array}{l}0.2998 * * * \\
(6.94)\end{array}$ \\
\hline SIZE & $\begin{array}{c}-0.0050 * * * \\
(-5.85)\end{array}$ & $\begin{array}{c}-0.0139 * * * \\
(-7.35)\end{array}$ & $\begin{array}{c}-0.0052 * * * \\
(-5.98)\end{array}$ & $\begin{array}{c}-0.0149 * * * \\
(-7.93)\end{array}$ \\
\hline LIQUIDITY & $\begin{array}{l}0.0214^{* *} \\
(2.13)\end{array}$ & $\begin{array}{l}0.0148 \\
(1.31)\end{array}$ & $\begin{array}{l}0.0187^{* *} \\
(2.24)\end{array}$ & $\begin{array}{l}0.0158 \\
(1.64)\end{array}$ \\
\hline CAPITAL & $\begin{array}{c}0.0052^{* *} \\
(2.48)\end{array}$ & $\begin{array}{l}0.0019 \\
(0.84)\end{array}$ & $\begin{array}{l}0.0068 * * * \\
(3.26)\end{array}$ & $\begin{array}{c}0.0042^{*} \\
(1.85)\end{array}$ \\
\hline Z-SCORE & $\begin{array}{l}-0.0120 * * \\
(-2.19)\end{array}$ & $\begin{array}{l}-0.0093 \\
(-1.60)\end{array}$ & $\begin{array}{c}-0.0129 * * * \\
(-2.7 I)\end{array}$ & $\begin{array}{c}-0.0122 * * \\
(-2.39)\end{array}$ \\
\hline NONINTEREST & $\begin{array}{c}-0.0226 * * \\
(-2.57)\end{array}$ & $\begin{array}{c}-0.025 I^{* *} \\
(-2.57)\end{array}$ & $\begin{array}{c}-0.0255^{* * *} \\
(-3.23)\end{array}$ & $\begin{array}{c}-0.0304 * * * \\
(-3.42)\end{array}$ \\
\hline OVERHEAD & $\begin{array}{c}0.3627^{* * * *} \\
(3.76)\end{array}$ & $\begin{array}{c}0.3469 * * * \\
(3.27)\end{array}$ & $\begin{array}{c}0.3424 * * * \\
(4.04)\end{array}$ & $\begin{array}{c}0.2948^{* * * *} \\
(3.13)\end{array}$ \\
\hline$\triangle G D P p c$ & $\begin{array}{c}-0.0004 * \\
(-1.87)\end{array}$ & $\begin{array}{c}-0.0005^{* *} \\
(-2.22)\end{array}$ & $\begin{array}{c}-0.0002 \\
(-1.45)\end{array}$ & $\begin{array}{c}-0.0004 * * \\
(-1.94)\end{array}$ \\
\hline RECESSION & $\begin{array}{c}-0.0042 \\
(-1.39)\end{array}$ & $\begin{array}{c}-0.0022 \\
(-0.72)\end{array}$ & $\begin{array}{l}0.0010 \\
(0.58)\end{array}$ & $\begin{array}{c}0.0023 \\
(1.22)\end{array}$ \\
\hline Country dummies & YES & NO & YES & NO \\
\hline Year dummies & YES & YES & YES & YES \\
\hline Wald Test & $212.15^{* * *}$ & - & $249.62^{* * * *}$ & - \\
\hline $\mathrm{F}-$ Test & - & $6.44 * * *$ & - & $8.60 * * *$ \\
\hline $\mathrm{R}^{2}$ & 0.1748 & 0.1154 & 0.1681 & 0.1147 \\
\hline First-stage Wald Test & $3.89 * *$ & $4.19 * *$ & $3.89 * *$ & $4.19 * *$ \\
\hline Hausman Test & - & $62.14^{* * *}$ & - & $78.07^{* * *}$ \\
\hline \# Observations & 2,806 & 2,806 & 2,806 & 2,806 \\
\hline \# Banks & 735 & 735 & 735 & 735 \\
\hline \# Countries & 17 & 17 & 17 & 17 \\
\hline
\end{tabular}


Table 6: GFC, bank market power, and loans growth: influence of bank regulation and supervision

This table presents results examining if bank regulation and supervision shape the effect of the GFC and the Lerner index on loans growth. The dependent variable ( $\triangle$ LOANS) is annual growth rate in net loans by individual banks. GFC is a dummy variable identifying the crisis period in each country. LERNERp are the predicted values of the Lerner index obtained from the first stage estimations. RESTRICTI is an index identifying the extent to which all types of non-traditional banking activities (insurance, real estate, securities, and participation on the capital and control of non-financial firms) are prohibited, restricted or permitted in each country. RESTRICT2 indicates the legal restrictions for banks on insurance, real estate, and securities activities. OWN refers to the legal restrictions for banks to participate in the ownership and control of non-financial firms. CAPREG is an index referred to the stringency of regulation on bank capital. SUPPOW refers to the supervisory power by official banking authorities. MONITOR is an index referred to the private monitoring executed on banking activities. SIZE is the natural logarithm of total bank assets. LIQUIDITY is the share of liquid assets in total assets. OVERHEAD is personnel expenses and other non-interest expenses over total assets. ZSCORE is the natural logarithm of the Z-score. Z-score is the return on assets plus the capital asset ratio divided by the standard deviation of asset returns. A four-year moving window is used to estimate the standard deviation of asset returns for each bank in each year. NONINTEREST is the non-interest income to total revenue ratio. CAPITAL is the bank's own capital-to-total assets ratio. $\triangle G D P p c$ is the annual growth rate in real GDP per capita. RECESSION is a dummy variable that takes value I if it is a year classified as a recession year following the Braun and Larrain (2005) methodology. ***; ** and * indicate statistical significance at I, 5, and I0 percent, respectively.

\begin{tabular}{|c|c|c|c|c|c|c|}
\hline $\begin{array}{l}\text { Dependent variable: } \\
\text { LOANS GROWTH }\end{array}$ & (I) & (2) & (3) & (4) & (5) & (6) \\
\hline GFC & $\begin{array}{c}-0.2304 * * * \\
(-4.21)\end{array}$ & $\begin{array}{c}-0.2294 * * * * \\
(-4.69)\end{array}$ & $\begin{array}{c}-0.2162 * * * \\
(-4.18)\end{array}$ & $\begin{array}{c}-0.2298 * * * \\
(-4.36)\end{array}$ & $\begin{array}{c}-0.2275 * * * * \\
(-4.37)\end{array}$ & $\begin{array}{c}-0.2442 * * * \\
(-4.74)\end{array}$ \\
\hline LERNERp & $\begin{array}{l}0.2824 \\
(1.44)\end{array}$ & $\begin{array}{c}0.3747^{*} \\
(1.81)\end{array}$ & $\begin{array}{c}0.2262 \\
(1.23)\end{array}$ & $\begin{array}{l}0.3322^{*} \\
(1.85)\end{array}$ & $\begin{array}{c}0.3037 \\
(1.33)\end{array}$ & $\begin{array}{c}0.5 \mid 45 * * \\
(2.38)\end{array}$ \\
\hline LERNERP * GFC & $\begin{array}{c}0.453 I^{* * * *} \\
(6.50)\end{array}$ & $\begin{array}{c}0.4276 * * * * \\
(6.68)\end{array}$ & $\begin{array}{c}0.4010^{* * * *} \\
(7.01)\end{array}$ & $\begin{array}{c}0.3779 * * * \\
(5.46)\end{array}$ & $\begin{array}{c}0.6318^{* * * *} \\
(4.41)\end{array}$ & $\begin{array}{c}0.4|4| * * * \\
(4.4 I)\end{array}$ \\
\hline LERNERP * GFC * RESTRICTI & $\begin{array}{c}-0.0149 * * \\
(-2.60)\end{array}$ & & & & & \\
\hline LERNERP * GFC * RESTRICT2 & & $\begin{array}{c}-0.0127^{* *} \\
(-2.35)\end{array}$ & & & & \\
\hline LERNERP * GFC * OWN & & & $\begin{array}{c}-0.0228 * * \\
(-2.35)\end{array}$ & & & \\
\hline LERNERp * GFC * CAPREG & & & & $\begin{array}{l}-0.0079 \\
(-1.19)\end{array}$ & & \\
\hline LERNERP * GFC * SUPPOW & & & & & $\begin{array}{c}-0.0234 * * \\
(-2.30)\end{array}$ & \\
\hline LERNERP * GFC * MONITOR & & & & & & $\begin{array}{l}-0.0082 \\
(-1.04)\end{array}$ \\
\hline RESTRICTI & $\begin{array}{c}0.0020 * * * \\
(2.43)\end{array}$ & & & & & \\
\hline RESTRICT2 & & $\begin{array}{c}0.0017^{* *} \\
(2.32)\end{array}$ & & & & \\
\hline OWN & & & $\begin{array}{c}0.0044 * * \\
(2.46)\end{array}$ & & & \\
\hline CAPREG & & & & $\begin{array}{c}-0.0002 \\
(-0.48)\end{array}$ & & \\
\hline SUPPOW & & & & & $\begin{array}{l}-0.0004 \\
(-1.29)\end{array}$ & \\
\hline MONITOR & & & & & & $\begin{array}{l}-0.0009 \\
(-1.08)\end{array}$ \\
\hline$\triangle G D P p c$ & $\begin{array}{c}-0.0006 * * \\
(-2.45)\end{array}$ & $\begin{array}{l}-0.0007^{*} \\
(-1.73)\end{array}$ & $\begin{array}{c}-0.0005 * * \\
(-2.35)\end{array}$ & $\begin{array}{c}-0.0006 * * \\
(-2.45)\end{array}$ & $\begin{array}{l}-0.0005 * * \\
(-2.12)\end{array}$ & $\begin{array}{l}-0.0006 \\
(-1.08)\end{array}$ \\
\hline RECESSION & $\begin{array}{l}-0.0044 \\
(-1.25)\end{array}$ & $\begin{array}{l}-0.0065 \\
(-1.56)\end{array}$ & $\begin{array}{c}-0.0034 \\
(-0.98)\end{array}$ & $\begin{array}{l}-0.0052 \\
(-1.53)\end{array}$ & $\begin{array}{l}-0.0050 \\
(-1.45)\end{array}$ & $\begin{array}{c}-0.0088^{* *} \\
(-2.13)\end{array}$ \\
\hline Bank-level control variables & YES & YES & YES & YES & YES & YES \\
\hline Year dummies & YES & YES & YES & YES & YES & YES \\
\hline $\mathrm{F}-$ Test & $7.49 * * *$ & $7.96^{* * * *}$ & $7.45^{* * * *}$ & $7.16^{\text {**** }}$ & $7.64 * * *$ & $7.62 * * *$ \\
\hline $\mathrm{R}^{2}$ & 0.0902 & 0.0879 & 0.0876 & 0.0928 & 0.0932 & 0.0890 \\
\hline \# Observations & 2,697 & 2,658 & 2,697 & 2,701 & 2,679 & 2,659 \\
\hline \# Banks & 723 & 722 & 723 & 723 & 723 & 721 \\
\hline \# Countries & 16 & 16 & 16 & 16 & 16 & 16 \\
\hline
\end{tabular}


Table 7: GFC and loans growth: the effect of bank market power. Alternative definition of Lerner

This table presents results examining the direct effect GFC on loans growth and its effect through changes in bank market power. An alternative measure of bank market power is considered. It is based on Koetter et al. (20I2) and eliminates the conventional assumption of full efficiency in the traditional Lerner index estimation. The dependent variable ( $\triangle$ LOANS) is the annual growth rate in net loans by individual banks. GFC is a dummy variable identifying the crisis period in each country. LERNERP are the predicted values of the adjusted Lerner index obtained from the first stage estimations. In PANEL A, we present the results of analyzing the direct effect of the global financial crisis on bank credit supply (coefficient of GFC). In PANEL B, we also show the indirect effect through changes in bank market power occurred during the crisis (coefficient of LERNERp*GFC). Columns (I) and (3) report the results of random effects estimations. Columns (2) and (4) report the results of fixed effects estimations. SIZE is the natural logarithm of total bank assets. LIQUIDITY is the share of liquid assets in total assets. OVERHEAD is personnel expenses and other non-interest expenses over total assets. ZSCORE is the natural logarithm of the Z-score. Z-score is the return on assets plus the capital asset ratio divided by the standard deviation of asset returns. A four-year moving window is used to estimate the standard deviation of asset returns for each bank in each year. NONINTEREST is the non-interest income to total revenue ratio. CAPITAL is the bank's own capital-to-total assets ratio. $\triangle$ GDPpc is the annual growth rate in real GDP per capita RECESSION is a dummy variable that takes value $I$ if it is a year classified as a recession year following the Braun and Larrain (2005) methodology. ***; ** and * indicate statistical significance at I, 5, and 10 percent, respectively.

\begin{tabular}{|c|c|c|c|c|}
\hline \multirow[b]{2}{*}{$\begin{array}{l}\text { Dependent variable: } \\
\text { LOANS GROWTH }\end{array}$} & \multicolumn{2}{|c|}{$\begin{array}{c}\text { PANEL A: } \\
\text { Direct effect of GFC }\end{array}$} & \multicolumn{2}{|c|}{$\begin{array}{l}\text { PANEL B: } \\
\text { Indirect effect through LERNER }\end{array}$} \\
\hline & (I) & (2) & (4) & (5) \\
\hline GFC & $\begin{array}{c}-0.0903^{2} \\
(-1.78)\end{array}$ & $\begin{array}{l}-0.1211 * \\
(-1.74)\end{array}$ & $\begin{array}{c}-0.1675^{* * * *} \\
(-3.13)\end{array}$ & $\begin{array}{c}-0.7238 * * * * \\
(-6.73)\end{array}$ \\
\hline LERNERp & $\begin{array}{c}4.0802 * \\
(1.91)\end{array}$ & $\begin{array}{c}3.8333 \\
(1.59)\end{array}$ & $\begin{array}{l}2.4371 \\
(1.13)\end{array}$ & $\begin{array}{l}7.5018 * * * \\
(3.08)\end{array}$ \\
\hline LERNERp * GFC & & & $\begin{array}{l}0.1176 * * * \\
(4.51)\end{array}$ & $\begin{array}{l}0.5175^{* * * *} \\
(7.30)\end{array}$ \\
\hline SIZE & $\begin{array}{c}-0.0105^{* * * *} \\
(-2.66)\end{array}$ & $\begin{array}{c}-0.0393 * * \\
(-2.19)\end{array}$ & $\begin{array}{c}-0.0075^{*} \\
(-1.88)\end{array}$ & $\begin{array}{c}-0.0678 * * * * \\
(-3.74)\end{array}$ \\
\hline LIQUIDITY & $\begin{array}{l}0.0006 \\
(0.16)\end{array}$ & $\begin{array}{l}0.0560 \\
(1.47)\end{array}$ & $\begin{array}{l}-0.0000 \\
(-0.01)\end{array}$ & $\begin{array}{l}0.1202 * * * \\
(3.11)\end{array}$ \\
\hline CAPITAL & $\begin{array}{l}-0.0024 \\
(-0.94)\end{array}$ & $\begin{array}{l}-0.0080^{*} \\
(-1.69)\end{array}$ & $\begin{array}{l}-0.0003 \\
(-0.14)\end{array}$ & $\begin{array}{c}-0.0142 * * * \\
(-2.98)\end{array}$ \\
\hline Z-SCORE & $\begin{array}{l}0.0081 * \\
(1.72)\end{array}$ & $\begin{array}{l}0.0182 \\
(1.64)\end{array}$ & $\begin{array}{c}0.0048 \\
(1.02)\end{array}$ & $\begin{array}{c}0.0357^{* * * *} \\
(3.17)\end{array}$ \\
\hline NONINTEREST & $\begin{array}{c}-0.065 I^{* *} \\
(-2.07)\end{array}$ & $\begin{array}{c}-0.0770 * \\
(-1.8 I)\end{array}$ & $\begin{array}{c}-0.04 \mid 4 \\
(-|.3|)\end{array}$ & $\begin{array}{c}-0.1388 * * * \\
(-3.24)\end{array}$ \\
\hline OVERHEAD & $\begin{array}{c}2.5330 * * \\
(2.10)\end{array}$ & $\begin{array}{l}\mathrm{I} .6857^{* *} \\
(2.08)\end{array}$ & $\begin{array}{l}1.6026 \\
(1.32)\end{array}$ & $\begin{array}{c}2.8706 * * * \\
(3.53)\end{array}$ \\
\hline$\triangle G D P p c$ & $\begin{array}{c}0.0006 \\
(1.05)\end{array}$ & $\begin{array}{c}0.0002 \\
(0.52)\end{array}$ & $\begin{array}{c}0.000 \mathrm{I} \\
(0.24)\end{array}$ & $\begin{array}{c}0.0011 * \\
(1.96)\end{array}$ \\
\hline RECESSION & $\begin{array}{c}-0.0002 \\
(-0.12)\end{array}$ & $\begin{array}{c}0.0008 \\
(0.38)\end{array}$ & $\begin{array}{c}-0.0023 \\
(-1.13)\end{array}$ & $\begin{array}{c}0.0009 \\
(0.45)\end{array}$ \\
\hline Country dummies & YES & NO & YES & NO \\
\hline Year dummies & YES & YES & YES & YES \\
\hline Wald Test & $221.41 * * *$ & - & $243.05 * * *$ & - \\
\hline F- Test & - & $6.14 * * *$ & - & $8.93^{* * *}$ \\
\hline $\mathrm{R}^{2}$ & 0.2088 & 0.1312 & 0.2112 & 0.1352 \\
\hline Hausman Test & - & $44.45 * * *$ & - & $62.93 * * *$ \\
\hline \# Observations & 2,481 & 2,481 & 2,481 & 2,481 \\
\hline \# Banks & 670 & 670 & 670 & 670 \\
\hline \# Countries & 17 & 17 & 17 & 17 \\
\hline
\end{tabular}


Table 8: GFC and loans growth: capital and liquidity constraints

This table presents results examining the effect of the GFC on loans growth. PANEL A shows the results obtained for low and high capitalized banks. PANELS B and C present the results examining the effect of the GFC on loans growth in banks with low/high liquid assets-to-liabilities ratio, and in banks with low/high customer deposits-to-total debt ratio, respectively. The dependent variable ( $\triangle$ LOANS) is the annual growth rate in net loans by individual banks. GFC is a dummy variable identifying the crisis period in each country. LERNER is the observed value of the Lerner index. SIZE is the natural logarithm of total bank assets. LIQUIDITY is the share of liquid assets in total assets. OVERHEAD is personnel expenses and other non-interest expenses over total assets. ZSCORE is the natural logarithm of the Z-score. Z-score is the return on assets plus the capital asset ratio divided by the standard deviation of asset returns. A four-year moving window is used to estimate the standard deviation of asset returns for each bank in each year. NONINTEREST is the non-interest income to total revenue ratio. CAPITAL is the bank's own capital-to-total assets ratio. $\triangle G D P p c$ is the annual growth rate in real GDP per capita. RECESSION is a dummy variable that takes value I if it is a year classified as a recession year following the Braun and Larrain (2005) methodology. ${ }^{* * *}$; $* *$ and $*$ indicate statistical significance at I, 5 , and I 0 percent, respectively.

\begin{tabular}{|c|c|c|c|c|c|c|}
\hline \multirow[b]{2}{*}{ Dependent variable: } & \multicolumn{2}{|c|}{$\begin{array}{c}\text { PANEL A: } \\
\text { Capital-to-assets }\end{array}$} & \multicolumn{2}{|c|}{$\begin{array}{c}\text { PANEL B: } \\
\text { Liquid assets- } \\
\text { to-liquid liabilities }\end{array}$} & \multicolumn{2}{|c|}{$\begin{array}{c}\text { PANEL C: } \\
\text { Customer deposits- } \\
\text { to-total debt }\end{array}$} \\
\hline & (I) & (2) & (3) & (4) & (5) & (6) \\
\hline LOANS GROWTH & LOW & HIGH & LOW & HIGH & LOW & HIGH \\
\hline GFC & $\begin{array}{c}-0.0030 * * \\
(-2.46)\end{array}$ & $\begin{array}{l}-0.0097 \\
(-0.44)\end{array}$ & $\begin{array}{c}-0.0334 \\
(-0.47)\end{array}$ & $\begin{array}{c}-0.0081 \\
(-1.05)\end{array}$ & $\begin{array}{l}-0.0062 \\
(-0.95)\end{array}$ & $\begin{array}{c}-0.0007 \\
(-0.27)\end{array}$ \\
\hline LERNER & $\begin{array}{c}0.0037 \\
(1.25)\end{array}$ & $\begin{array}{l}-0.0184 * * \\
(-1.98)\end{array}$ & $\begin{array}{c}0.1426 \\
(0.78)\end{array}$ & $\begin{array}{c}-0.00009 \\
(-0.03)\end{array}$ & $\begin{array}{l}-0.0113 \\
(-1.32)\end{array}$ & $\begin{array}{l}-0.0114 \\
(-1.46)\end{array}$ \\
\hline SIZE & $\begin{array}{c}-0.0029 * * * \\
(-3.44)\end{array}$ & $\begin{array}{c}-0.0118 * * * \\
(-4.79)\end{array}$ & $\begin{array}{l}-0.0094 \\
(-0.15)\end{array}$ & $\begin{array}{c}-0.0072 * * * \\
(-9.19)\end{array}$ & $\begin{array}{l}-0.0024 \\
(-1.09)\end{array}$ & $\begin{array}{c}-0.0076 * * * \\
(-3.92)\end{array}$ \\
\hline LIQUIDITY & $\begin{array}{c}0.0019 \\
(0.85)\end{array}$ & $\begin{array}{c}-0.0066 \\
(-0.81)\end{array}$ & & & & \\
\hline CAPITAL & & & $\begin{array}{l}-0.0353 \\
(-1.26)\end{array}$ & $\begin{array}{l}0.0018 * * * \\
(2.75)\end{array}$ & $\begin{array}{l}0.0095 * * * \\
(2.73)\end{array}$ & $\begin{array}{c}-0.0033^{*} \\
(-1.95)\end{array}$ \\
\hline Z-SCORE & $\begin{array}{l}-0.0005 \\
(-0.84)\end{array}$ & $\begin{array}{l}-0.0005 \\
(-0.20)\end{array}$ & $\begin{array}{l}-0.0527 \\
(-0.89)\end{array}$ & $\begin{array}{c}-0.00006 \\
(-0.08)\end{array}$ & $\begin{array}{c}-0.0002 \\
(-0.07)\end{array}$ & $\begin{array}{c}0.0010 \\
(0.46)\end{array}$ \\
\hline NONINTEREST & $\begin{array}{l}-0.0022 \\
(-0.66)\end{array}$ & $\begin{array}{l}-0.0117 \\
(-1.59)\end{array}$ & $\begin{array}{c}-0.6068 * * * \\
(-2.91)\end{array}$ & $\begin{array}{l}0.0030 \\
(1.27)\end{array}$ & $\begin{array}{c}0.0042 \\
(0.52)\end{array}$ & $\begin{array}{c}-0.0160 * * \\
(-2.47)\end{array}$ \\
\hline OVERHEAD & $\begin{array}{c}0.0426 \\
(0.91)\end{array}$ & $\begin{array}{c}0.234 I^{* * * *} \\
(3.54)\end{array}$ & $\begin{array}{c}7.1131 * * * * \\
(4.34)\end{array}$ & $\begin{array}{c}-0.0008 \\
(-0.04)\end{array}$ & $\begin{array}{c}0.0176 \\
(0.8)\end{array}$ & $\begin{array}{c}0.2897 * * * \\
(4.72)\end{array}$ \\
\hline$\triangle G D P p c$ & $\begin{array}{c}-0.0003 \text { ** } \\
(-2.38)\end{array}$ & $\begin{array}{c}-0.0004 \\
(-1.58)\end{array}$ & $\begin{array}{c}-0.0057 \\
(-0.58)\end{array}$ & $\begin{array}{c}-0.000 I^{* *} \\
(-2.03)\end{array}$ & $\begin{array}{l}0.0008 \\
(1.20)\end{array}$ & $\begin{array}{c}-0.0005^{* *} \\
(-2.53)\end{array}$ \\
\hline RECESSION & $\begin{array}{c}-0.0006 \\
(-0.87)\end{array}$ & $\begin{array}{c}0.0027 \\
(1.16) \\
\end{array}$ & $\begin{array}{c}-0.0168 \\
(-0.28)\end{array}$ & $\begin{array}{c}0.0020 * * * \\
(2.73)\end{array}$ & $\begin{array}{c}-0.0033 \\
(-1.54) \\
\end{array}$ & $\begin{array}{c}-0.0032^{* *} \\
(-2.06)\end{array}$ \\
\hline Year dummies & YES & YES & YES & YES & YES & YES \\
\hline $\mathrm{F}-$ Test & $2.79 * * *$ & $5.07 * * *$ & $5.89 * * *$ & $8.38 * * *$ & $2.24 * *$ & $5.96 * * *$ \\
\hline $\mathrm{R}^{2}$ & 0.0916 & 0.0563 & 0.4730 & 0.0933 & 0.2861 & 0.0519 \\
\hline \# Observations & 601 & 1,899 & 103 & 2,397 & $13 \mid$ & 2,353 \\
\hline \# Banks & 166 & 518 & 34 & 650 & 42 & 635 \\
\hline
\end{tabular}


Table 9: GFC, bank market power, and loans growth: the importance of relationship lending

This table presents results examining potential reverse causality between bank market power and lending relationships. PANELS A and B classify banks according to their level of specialization in traditional bank activities (NONINTEREST variable) and size (SIZE variable), respectively. In Panel C, we split the sample of banks according to the $75^{\text {th }}$ percentile of the variable proxying for the level of institutional quality of each country: the Rule of Law indicator. The dependent variable ( $\triangle$ LOANS) is annual growth rate in net loans by individual banks. GFC is a dummy variable identifying the crisis period in each country. LERNERp are the predicted values of the Lerner index obtained from the first stage estimations. SIZE is the natural logarithm of total bank assets. LIQUIDITY is the share of liquid assets in total assets. OVERHEAD is personnel expenses and other non-interest expenses over total assets. ZSCORE is the natural logarithm of the Z-score. Z-score is the return on assets plus the capital asset ratio divided by the standard deviation of asset returns. A four-year moving window is used to estimate the standard deviation of asset returns for each bank in each year. NONINTEREST is the non-interest income to total revenue ratio. CAPITAL is the bank's own capital-to-total assets ratio. $\triangle$ GDPpc is the annual growth rate of real GDP per capita. RECESSION is a dummy variable that takes value I if it is a year classified as a recession year following the Braun and Larrain (2005) methodology. $* * * ; *$ and $*$ indicate statistical significance at $\mathrm{I}, 5$, and 10 percent, respectively.

\begin{tabular}{|c|c|c|c|c|c|c|}
\hline \multirow[b]{2}{*}{$\begin{array}{l}\text { Dependent variable: } \\
\text { LOANS GROWTH }\end{array}$} & \multicolumn{2}{|c|}{$\begin{array}{c}\text { PANEL A } \\
\text { SPECIALIZATION }\end{array}$} & \multicolumn{2}{|c|}{$\begin{array}{l}\text { PANEL B } \\
\text { SIZE }\end{array}$} & \multicolumn{2}{|c|}{$\begin{array}{c}\text { PANEL C } \\
\text { INSTITUTIONAL QUALITY }\end{array}$} \\
\hline & $\begin{array}{c}\text { (I) } \\
\text { NON-TRADITIONAL } \\
\text { ACTIVITIES }\end{array}$ & $\begin{array}{c}(2) \\
\text { TRADITIONAL } \\
\text { ACTIVITIES }\end{array}$ & $\begin{array}{c}\text { (3) } \\
\text { LARGE }\end{array}$ & $\begin{array}{c}\text { (4) } \\
\text { SMALL }\end{array}$ & $\begin{array}{l}\text { (5) } \\
\text { HIGH }\end{array}$ & $\begin{array}{l}\text { (6) } \\
\text { LoW }\end{array}$ \\
\hline GFC & $\begin{array}{l}-0.0853^{* * * *} \\
(-3.22)\end{array}$ & $\begin{array}{l}-0.0132 * \\
(-1.72)\end{array}$ & $\begin{array}{c}-0.0164 * * * \\
(-3.18)\end{array}$ & $\begin{array}{c}-0.1217 * * * \\
(-3.45)\end{array}$ & $\begin{array}{c}-0.0582^{* * *} \\
(-3.04)\end{array}$ & $\begin{array}{l}-0.2680 * * * \\
(-6.21)\end{array}$ \\
\hline LERNERp & $\begin{array}{c}0.0978 \\
(0.33)\end{array}$ & $\begin{array}{l}-0.07 \mid 4 \\
(-1.45)\end{array}$ & $\begin{array}{c}0.0064 \\
(0.49)\end{array}$ & $\begin{array}{l}0.0102 \\
(0.05)\end{array}$ & $\begin{array}{l}0.1186 \\
(1.19)\end{array}$ & $\begin{array}{l}0.5752 \\
(1.32)\end{array}$ \\
\hline LERNERp * GFC & $\begin{array}{l}0.5377^{* * * *} \\
(6.23)\end{array}$ & $\begin{array}{l}0.0409 \\
(1.20)\end{array}$ & $\begin{array}{c}0.0272^{* * * *} \\
(3.28)\end{array}$ & $\begin{array}{l}0.9794^{* * * *} \\
(4.70)\end{array}$ & $\begin{array}{l}0.0708 * * * \\
(4.23)\end{array}$ & $\begin{array}{l}1.7875^{* * * *} \\
(8,48)\end{array}$ \\
\hline SIZE & $\begin{array}{c}-0.0197 * * * \\
(-4.93)\end{array}$ & $\begin{array}{c}-0.0088 * * * \\
(-7.46)\end{array}$ & $\begin{array}{c}-0.0036 \text { *** } \\
(-12.23)\end{array}$ & $\begin{array}{c}-0.0293 * * * \\
(-8.25)\end{array}$ & $\begin{array}{c}-0.0053^{* * *} \\
(-6.22)\end{array}$ & $\begin{array}{c}-0.025 \mathrm{I} * * * \\
(-3.5 \mathrm{I})\end{array}$ \\
\hline LIQUIDITY & $\begin{array}{l}0.0060 \\
(0.29)\end{array}$ & $\begin{array}{c}0.0052 \\
(0.96)\end{array}$ & $\begin{array}{c}0.0020 * * \\
(2.28)\end{array}$ & $\begin{array}{c}0.0087 \\
(0.55)\end{array}$ & $\begin{array}{c}0.0198 * * * \\
(2.98)\end{array}$ & $\begin{array}{l}0.0522 \\
(1.58)\end{array}$ \\
\hline CAPITAL & $\begin{array}{c}0.0023 \\
(0.54)\end{array}$ & $\begin{array}{c}0.0008 \\
(0.69)\end{array}$ & $\begin{array}{c}0.0000 \\
(0.20)\end{array}$ & $\begin{array}{c}0.0085 \\
(1.55)\end{array}$ & $\begin{array}{c}0.0048 * * * \\
(4.22)\end{array}$ & $\begin{array}{c}0.0060 \\
(0.88)\end{array}$ \\
\hline Z-SCORE & $\begin{array}{c}-0.0086 \\
(-0.78)\end{array}$ & $\begin{array}{c}0.0030 \\
(1.61)\end{array}$ & $\begin{array}{c}0.0001 \\
(0.17)\end{array}$ & $\begin{array}{c}-0.0095 \\
(-1.08)\end{array}$ & $\begin{array}{c}-0.0056 \\
(-1.6 I)\end{array}$ & $\begin{array}{c}-0.0296 * \\
(-1.72)\end{array}$ \\
\hline NONINTEREST & $\begin{array}{c}-0.044 I^{* *} \\
(-2.47)\end{array}$ & $\begin{array}{c}0.0121^{* * * *} \\
(2.75)\end{array}$ & $\begin{array}{c}-0.0020 * \\
(-1.77)\end{array}$ & $\begin{array}{l}-0.0160 \\
(-1.00)\end{array}$ & $\begin{array}{l}-0.0060 \\
(-1.06)\end{array}$ & $\begin{array}{c}-0.0535^{* *} \\
(-1.98)\end{array}$ \\
\hline OVERHEAD & $\begin{array}{c}0.1368 \\
(0.68)\end{array}$ & $\begin{array}{c}0.1953 * * * \\
(3.43)\end{array}$ & $\begin{array}{c}-0.0086 \\
(-0.77)\end{array}$ & $\begin{array}{c}0.2836^{* *} \\
(2.06)\end{array}$ & $\begin{array}{l}0.0653 \\
(1.02)\end{array}$ & $\begin{array}{c}1.0357 * * * \\
(3.21)\end{array}$ \\
\hline$\triangle G D P p c$ & $\begin{array}{l}-0.0004 \\
(-1.20)\end{array}$ & $\begin{array}{c}-0.0004 * * \\
(-2.20)\end{array}$ & $\begin{array}{c}-0.000 I^{* * * *} \\
(-4.60)\end{array}$ & $\begin{array}{c}-0.0001 \\
(-0.23)\end{array}$ & $\begin{array}{c}0.00009 \\
(0.49)\end{array}$ & $\begin{array}{c}-0.0007 \\
(-1.63)\end{array}$ \\
\hline RECESSION & $\begin{array}{c}-0.0004 \\
(-0.07) \\
\end{array}$ & $\begin{array}{c}-0.0028 \\
(-1.57) \\
\end{array}$ & $\begin{array}{c}-0.0005 \\
(-1.36) \\
\end{array}$ & $\begin{array}{c}-0.0043 \\
(-0.52) \\
\end{array}$ & $\begin{array}{c}-0.0023 \\
(-1.17) \\
\end{array}$ & $\begin{array}{c}-0.0012 \\
(-0.15) \\
\end{array}$ \\
\hline Year dummies & YES & YES & YES & YES & YES & YES \\
\hline F Test & $5.18^{* * * *}$ & $9.87^{* * * *}$ & $\left.13.4\right|^{* * *}$ & $8.62^{* * *}$ & $7.45^{* * * *}$ & $8.91 * * *$ \\
\hline \# Banks & 314 & 421 & 551 & 184 & 536 & 199 \\
\hline
\end{tabular}

